\title{
ВЕРХНЕРИФЕЙСКО-ВЕНДСКИЕ ОТЛОЖЕНИЯ БАШКИРСКОГО МЕГАНТИКЛИНОРИЯ ЮЖНОГО УРАЛА: СОСТОЯНИЕ ИЗУЧЕННОСТИ И СТРАТИГРАФИЧЕСКОЕ РАСЧЛЕНЕНИЕ
}

Дуб С. А.

\begin{abstract}
Аннотация
На основе современных представлений об изменениях в биосфере, атмосфере, гидросфере (и, соответственно, в климате и ходе осадочных процессов) в интервале 1000-540 млн лет, с учётом предложений по совершенствованию Общей стратиграфической шкалы (ОСШ) докембрия [Дуб, в печати] и данных последних исследований, рассмотрен альтернативный существующему вариант стратиграфического расчленения верхнерифейско-вендских (примерно соответствующих неопротерозою Международной стратиграфической шкалы - МСШ) отложений Башкирского мегантиклинория (БМА). Подчёркивается необходимость жёсткого разграничения общих и местных стратиграфических подразделений. Представлены данные в пользу перевода зильмердакской свиты в ранг серии и отнесения трёх её нижних свит к среднему рифею / юрматинию. Показано, что время накопления каратауской серии (в составе катавской, инзерской, миньярской и укской свит) существенно меньше продолжительности позднего рифея /каратавия. Особое внимание уделено обсуждению возраста укской свиты (анализ имеющихся сведений позволил уточнить её стратиграфическое положение): наиболее вероятно, что она сформировалась в диапазоне 780-740 млн лет. Продемонстрирована высокая неопределённость стратиграфического положения вышележащих геологических тел. Бакеевскую, толпаровскую, суировскую, кургашлинскую свиты необходимо рассматривать в составе терминального рифея / аршиния. Аршинскую серию, состоящую из байнасской, махмутовской, игонинской и шумской свит в Тирлянской мульде, а также представленную криволукской свитой в Криволукской синклинали, не следует в полном объёме относить к терминальному рифею. Поднят вопрос об исключении бакеевской свиты и толпаровско-суировской последовательности из состава ашинской серии: вероятнее всего, эти отложения являются модификацией аршинской серии на западном крыле БМА. Отмечено, что урюкская свита, возможно, имеет довендский возраст. Интерпретированы существующие на текущий момент противоречивые данные о стратиграфии надурюкской части ашинской серии; проблемы возраста составляющих серию геологических тел и стратиграфического диапазона серии в целом по-прежнему требуют тщательной проработки.
\end{abstract}

\section{Ключевые слова:}

Верхний рифей, терминальный рифей, венд, неопротерозой, Башкирский мегантиклинорий, стратотип. 


\author{
С.А. Дуб \\ Институт геологии и геохимии УрО РАН, sapurins@gmail.com
}

\title{
ВВЕДЕНИЕ
}

Осадочные породы фиксируют особенности развития атмосферы, гидросферы и биосферы Земли. В частности, кардинальные изменения в составе газовой оболочки планеты и химии Мирового океана, а также своеобразные этапы эволюции живых организмов отражены в геологической летописи неопротерозоя МСШ (от 1000 до 540 млн лет). С данным отрезком геологического времени ассоциируют коренные изменения облика Земли [Planavsky et al., 2015], в том числе к нему приурочены крупнейшие в истории оледенения [Чумаков, 2015]: наиболее распространённая гипотеза характеризует состояние планеты в интервалах 717-660 и 650-635 млн лет (в криогении) словосочетаниями «снежный ком», или «Земля-снежок» - snowball Earth [Hoffman, 1998; Rooney et al., 2015; Hoffman et al., 2017].

Обнаружены свидетельства значительного роста содержания кислорода в атмосфере неопротерозоя, известного как «неопротерозойское кислородное событие» [Kump, 2008; Lyons et al., 2014], на фоне низкого - по сравнению с предшествующими эрами - парциального давления углекислого газа [Kasting, 1993; Sheldon, 2006; Cox et al., 2016], но точное время проявления этого события пока не известно (по-видимому, оно было многофазным) [Williams et al., 2019]. Считается, что при этом глубинные слои океана в основном оставались аноксидными [Canfield, 1998; Canfield et al., 2008; Sperling et al., 2015; Wallace et al., 2017], а отдельные бассейны осадконакопления могли являться «кислородными оазисами» [Sperling et al., 2014; Gilleaudeau, Kah, 2015; Маслов, Подковыров, 2018]. В эдиакарии океан эпизодически становился оксигенизированным [Sahoo et al., 2016]. В рассматриваемой эре морская вода оказалась менее насыщенной углекислотой по сравнению с более ранними этапами геологической истории [Grotzinger, 1990; Riding, 2006; Krissansen-Totton et al., 2018].

Предполагается, что эукариоты к этому времени уже существовали [Knoll et al., 2006; Butterfield, 2015], но стали таксономически более разнообразными только в тонии (от 1000 до 717 млн лет) [Сергеев, 2006; Cohen, McDonald, 2015]; 730 млн лет назад появились первые представители царства Хромиста [Cavalier-Smith, 2018], а позже примитивные животные [см. Love et al., 2009; Antcliffe, 2013; Nettersheim et al., 2019 и др.]: предполагаемые остатки Metazoa (в виде эмбрионов) обнаружены в отложениях с возрастом 600-633 млн лет [Xiao et al., 1998; Yin et al., 2007; Cunningham et al., 2017]. В интервале 570-540 млн лет в субаквальных экосистемах господствовали «мягкотелые» вендобионты и другие существа, которые не имеют аналогов в современном мире [Seilacher, 1992; Grazhdankin, 2004; Pu et al., 2016], в конце эдиакария-начале кембрия возникла и распространилась скелетная фауна [Porter, 2010; Erwin et al. 2011; Zhuravlev, Wood, 2018].

Известно, что в раннем неопротерозое завершилась сборка суперконтинента Родиния; её распад 850-700 млн лет назад сопровождался формированием крупных магматических провинций; в эдиакарии (635-541 млн лет) «осколки» Родинии объединились в Гондвану [Ernst et al., 2008; Li et al., 2008, 2013]. Однако взаимосвязи между колебаниями уровня моря, изменениями темпов образования океанической коры и 
глобальными оледенениями пока не ясны в полной мере [Liu, Peltier, 2013; Van der Meer et al., 2017; Bechstädt et al., 2018; Williams, Gostin, 2019].

Проблемам корреляции МСШ докембрия с Общей и региональными стратиграфическими шкалами России посвящено множество работ. В частности, в настоящее время принято считать, что неопротерозойской эре приблизительно соответствует позднерифейско-вендский интервал, отличающийся от неё несколько большей продолжительностью (как в сторону удревнения, так и омоложения) [Семихатов, 2000; Стратиграфический..., 2019; International chronostratigraphic chart, v2020/03]. Данная публикация, посвящённая стратиграфии неопротерозойских отложений БМА западного склона Южного Урала, ставит своей задачей привлечь внимание исследователей к вопросу сопоставления верхнерифейско-вендских отложений на территории России (и сопредельных стран) и неопротерозойских образований других регионов.

Территория БМА в позднем рифее представляла собой проксимальную часть пассивной окраины Восточно-Европейской платформы (шельф Родинии / Балтики) [Маслов и др., 2002; Раабен, 2007], к востоку от которой (в современных координатах) находился океанический бассейн [согласно Li et al., 2013]. По данным В.Н. Пучкова [2010], на вендский период приходится фаза тиманской складчатости и формирование орогена в обрамлении Балтики. Недавно появились основания утверждать, что на территории современного Южного Урала коллизия Восточно-Европейской платформы и тектонического блока с гетерогенным фундаментом произошла ещё раньше, а в вендекембрии на континентальной окраине возник активный вулкано-плутонический пояс [Рязанцев и др., 2019].

\section{АСПЕКТЫ СТРАТИГРАФИИ \\ ВЕРХНЕРИФЕЙСКО-ВЕНДСКИХ ОТЛОЖЕНИЙ БМА}

В пределах БМА к верхнему рифею-венду с той или иной степенью условности относят каратаускую, аршинскую и ашинскую серии. Отложения каратауской и ашинской серий присутствуют как на западном, так и на восточном крыльях БМА, тогда как на востоке в пределах разных геологических структур залегают разнородные по литологии отложения - аршинская серия (Тирлянская мульда), а также криволукская, кургашлинская и байназаровская свиты (Криволукская синклиналь), последние две свиты А.В. Масловым и В.Н. Пучковым относятся к ашинской серии (см. ссылки в подрисуночной подписи к рис. 1).

\section{Каратауская серия}

Разрез верхнего рифея стратотипической местности - каратауской серии - снизу вверх состоит из терригенной зильмердакской, существенно карбонатной катавской, карбонатно-терригенной инзерской, карбонатной миньярской и терригенно-карбонатной укской свит [Беккер, 1961; Маслов и др., 2001; Постановления..., 2010; Пучков и др., 2017]. Снизу и сверху серия ограничена несогласиями. Ещё один перерыв в осадконакоплении отмечается между миньярской и укской свитами [Кузнецов и др., 2014; Маслов, 2020].

Наличие перерыва в подошве серии иллюстрируется залеганием зильмердакской свиты на разных уровнях авзянской свиты юрматинской серии [Маслов, Анфимов, 2000 и ссылки в этой работе]. Но его продолжительность вызывает дискуссии. Имеющиеся данные С-изотопной хемостратиграфии по авзянской свите (свидетельствующие о её возрасте 1270 млн лет [Bartley et al., 2007]) и находка обломочного циркона с возрастом $964 \pm 57$ млн лет в низах зильмердакской свиты [Маслов и др., 2018а] заставляют 
предполагать весьма длительный интервал, не представленный в геологической летописи. С другой стороны, результаты межбассейновой корреляции отложений, основанные на сопоставлении карбонатов авзянской свиты с отложениями других осадочных бассейнов только по значениям величин $\delta^{13} \mathrm{C}$ [Bartley et al., 2007], не могут быть признаны надёжными (особенно в свете данных по изотопному составу углерода в карбонатах каратауской серии - см. ниже), равно как и известные до этого K-Ar датировки по глаукониту, составляющие 1226 млн лет [Стратотип.., 1983]. На более молодой возраст авзянской свиты указывают ассоциации микрофоссилий [Сергеев и др., 2010]. В нижней подсвите зильмердакской свиты только один обломочный циркон имеет возраст менее 1 млрд лет (без учёта погрешности) [Маслов и др., 2018а]. Кроме того, полученную ранее датировку 910-950 млн лет по детритовым ортоклазам в этой же подсвите [Glasmacher et al., 1999] на сегодня нельзя считать полностью валидной. Всё это пока не позволяет уверенно признать очень большую продолжительность (порядка 300 млн лет) перерыва между юрматинской и каратауской сериями.

В разрезе каратауской серии отсутствуют (или не обнаружены) прослои вулканогенно-осадочных пород, по этой причине стратиграфические подразделения верхнего рифея Южного Урала не имеют сколь-либо валидных U-Pb датировок. Однако об абсолютном возрасте некоторых свит можно судить благодаря использованию Г.В. Овчинниковой с коллегами $\mathrm{Pb}-\mathrm{Pb}$ метода датирования карбонатных пород: для нижней подсвиты инзерской свиты получен возраст $836 \pm 25$ млн лет [Овчинникова и др., 1998], а для средней части миньярской свиты - $780 \pm 85$ млн лет [Овчинникова и др., 2000]. Совершенствование указанной методики впоследствии позволило предоставить для примерно этих же уровней несколько иные датировки, соответственно $844 \pm 24$ и $820 \pm 77$ млн лет [Kuznetsov et al., 2017].

Кроме того, к 80-м годам XX века было опубликовано множество работ с результатами датирования K-Ar методом широко распространённого в отложениях каратауской серии глауконита. Так, значения / разброс значений возраста этого минерала в катавской свите составил 938 млн лет, в инзерской - 896-740 млн лет, в миньярской - 713681 млн лет, в укской - 658-630 млн лет [Гаррис, 1977; Стратотип..., 1983; Горохов и др., 2019; с учётом уточнения объёмов инзерской и миньярской свит в 1991 г.]. Позднее возраст раннего диагенеза отложений нижней части инзерской свиты оценивался Rb-Sr методом в пределах 830-806 млн лет [Gorokhov et al., 1995] или 836-803 млн лет [Горохов и др., 2019], а нижнеукской подсвиты - $688 \pm 10$ млн лет [Горожанин, Кутявин, 1986] и 663 \pm 9 млн лет [Зайцева и др. 2008]. Глауконит бакеевской свиты, несогласно перекрывающей верхнерифейские отложения на западном крыле БМА, имеет Rb-Sr возраст 650-630 млн лет [Зайцева и др., 2019].

Зильмердакская свита (состоящая снизу вверх из бирьянской, нугушской, лемезинской и бедерышинской подсвит) в разных районах и по разным оценкам имеет мощность в пределах 500-3300 м, что сопоставимо с суммарной мощностью отложений от катавской до укской свит включительно - от 1000 до 2700 м [Горяинова, Фалькова, 1937; Стратотип..., 1983; Пучков и др., 2017; Маслов, 2020]. Ряд исследователей подразделяет подсвиты зильмердакской свиты на толщи или связки [Горяинова, Фалькова, 1937; Козлов, 1982], что делает картину стратиграфического расчленения разреза более сложной. Отмечается, что граница между зильмердакской и катавской свитами отчётливо выражена [Стратотип..., 1983].

Важнейшую информацию о возрасте зильмердакской свиты предоставляют результаты изучения в ней комплексов микрофоссилий [Янкаускас, 1982; Вейс и др., 2003; 
Сергеев, 2006; Сергеев и др., 2010]. Так, в трёх нижних подсвитах присутствует комплекс остатков «Туруханского (среднерифейского) этапа» развития органического мира, возрастные рамки которого условно оцениваются в пределах 1200-1030 млн лет, тогда как типичные верхнерифейские формы (комплекс остатков «Учуро-Майского этапа» (1030850 млн лет), характерные для лахандинской серии Сибири) обнаруживаются только в самой верхней бедерышинской подсвите [Сергеев и др., 2010]. Приведённые сведения идут вразрез с классическими представлениями о принадлежности всей зильмердакской свиты к верхнему рифею. В то же время они хорошо согласуются с данными Г.А. Петрова [2018], указывающего на её литологическое сходство с ишеримской свитой среднего рифея Северного Урала, возраст которой оценивается в интервале 1150-1080 млн лет (корректнее, минимальный возрастной предел последней - $1079 \pm 41$ млн лет).

Бирьянско-нугушская последовательность сопоставляется с усинской свитой, лемезинская подсвита - с леонидовской свитой, а бедерышинская - с приютовской свитой абдулинской серии верхнего рифея Волго-Уральской области [Маслов и др., 2002], между тем усинскую свиту ряд авторов относит к нижележащей серафимовской серии среднего рифея [Стратиграфическая..., 2000; Сергеева и др., 2018].

По неопубликованным данным А.В. Маслова, в бирьянской подсвите зильмердакской свиты 102 зерна детритовых цирконов из 103-х имеют возраст более 1051 \pm 18 млн лет. При этом в лемезинской подсвите отсутствуют детритовые цирконы моложе $1817 \pm 59$ млн лет [Романюк и др., 2013].

Здесь также важно подчеркнуть очевидность того, что применительно к каратауской серии в целом некорректно вести речь о едином тектоно-седиментационном цикле развития осадочного бассейна. Начиная с зигальгинской свиты юрматинской серии в разрезе отсутствуют непосредственные свидетельства рифто- и орогенеза на данной территории, а накопление осадочных толщ происходило при пассивном тектоническом режиме. Вместе с тем, следует иметь в виду, что перерыв между юрматинской и каратауской сериями совпадает по времени с гренвильскими орогеническими событиями, слабо проявленные следы которых обнаруживаются на западном склоне Урала [Маслов и др., 2014, 2018а; Петров и др., 2015; Шардакова, 2018]. На это же время приходится один или несколько эпизодов тектоно-термальной активизации флюидов и формирование месторождений полезных ископаемых [Крупенин, 2004; Мичурин и др., 2018; Ковалев и др., 2020]. В соответствии с вышеприведёнными сведениями, аркозовые песчаники бирьянской подсвиты могут иметь молассовую природу (отвечая, предположительно, заключительным этапам денудации гор), тогда как кварцевые песчаники лемезинской подсвиты, несомненно, являются значительно более зрелыми.

Стратиграфически значимой для каратауской серии считается находка микрофоссилий Melanocyrillium в миньярской свите [Маслов и др., 1994]: предполагается, что панцирные амёбы, коим принадлежат эти остатки, появились не раньше 850 млн лет назад [Сергеев и др., 2010]. Необходимо отметить, что, по мнению А.Ф. Вейса с коллегами [2003], эта находка должна быть повторена.

Противоречивые свидетельства о возрасте характерны и для укской свиты. Приведённые выше датировки указывают, что она сформировалась во временном диапазоне 700-650 млн лет [Горожанин, Кутявин, 1986; Зайцева и др., 2008, 2019; Кузнецов и др., 2014]. Однако все остальные геологические данные это опровергают. В частности, в Тирлянской мульде на укской свите залегает аршинская серия, которая была отнесена к терминальному рифею [Козлов и др., 2011; Puchkov et al., 2014; Пучков и др., 2017]. Вулканические породы в составе этой серии имеют возраст 707 и 732 млн лет (U- 
$\mathrm{Pb}$ датирование цирконов [Краснобаев и др., 2012]) и $677 \pm 31$ млн лет (Rb-Sr [Горожанин, 1995]). Укская свита, венчая разрез верхнего рифея на западном крыле БМА, в структурном плане имеет с подстилающими отложениями гораздо больше общих черт (по распространённости и элементам залегания), нежели с перекрывающими. Несогласное залегание последних [Ларионов и др., 2015] и интенсивность вторичных преобразований пород верхней части укской свиты во многих разрезах указывает на длительный перерыв между ней и вышележащими образованиями.

Для укской свиты измеренное отношение ${ }^{87} \mathrm{Sr} /{ }^{86} \mathrm{Sr}$ в известняках, удовлетворяющих геохимическим критериям сохранности изотопных систем, составляет 0.70535-0.70611 [Кузнецов и др., 2003, 2014, 2018]. Но такие низкие значения стронциевого отношения согласно данным, приведенным в наиболее полной на сегодня работе А. Заки с соавторами [Zaky et al., 2019] - не характерны для криогениевых и более молодых отложений. В то же время, на основе Sr-изотопной систематики укская свита хорошо коррелирует с докриогениевой формацией Дидикама в Эфиопии: в синклинории Негаш карбонатные породы со значениями ${ }^{87} \mathrm{Sr} /{ }^{86} \mathrm{Sr}$ от 0,70519 до 0,70621 (значения возрастают снизу вверх по разрезу), согласно залегают на отложениях, в которых наиболее молодые детритовые цирконы имеют возраст 777 млн лет [Miller et al., 2009; Swanson-Hysell et al., 2015].

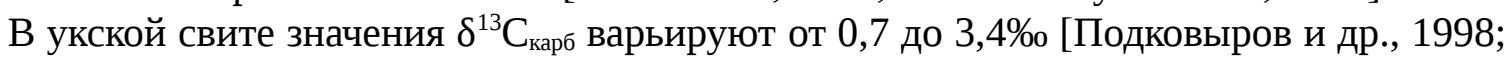
Кузнецов и др., 2006]. В эфиопской последовательности данный параметр в основном лежит в пределах 1-3\%, но вблизи её кровли отмечается глубокий отрицательный экскурс ${ }^{1}$ [Swanson-Hysell et al., 2015]. Поэтому на основе хемостратиграфических данных верхнеукская подсвита может условно сопоставляться с нижней и, возможно, средней частями формации Дидикама. Установлено, что эта формация древнее 735 млн лет [MacLennan, 2018].

Наконец, для верхнеукской подсвиты характерна пачка с многочисленными текстурами molar tooth (MT) [Дуб и др., 2018], которые, как считается, практически полностью исчезают из геологической летописи на уровне 717 млн лет - вблизи границы тония и криогения. Как исключение, находки этих текстур известны лишь в двух разрезах эдиакарских отложений, в каждом из которых они приурочены только к одному пласту и отражают специфику обстановок; достоверных свидетельств присутствия МТ-текстур в породах криогения (точнее, интервала от начала оледенения Стёрт до конца гляциопериода Марино) к настоящему моменту нет [James et al., 1998; Shields, 2002; Kuang, 2014; Fairchild et al., 2018; Hodgskiss et al., 2018 и многие другие].

\section{Аршинская серия}

Аршинская серия Тирлянской мульды восточного крыла БМА включает (снизу вверх) байнасскую, махмутовскую, игонинскую и шумскую свиты [Козлов и др., 2011]. Байнасская свита сложена сланцами, иногда с примесью карбонатного вещества;

${ }^{1}$ Г. Халверсон с коллегами [Halverson et al., 2018a, 2018б] установили, что к верхам тония приурочена не одна (Islay anomaly), а две глубокие отрицательные аномалии - Russøya anomaly (в интервале 735-740 млн лет) и Garvellach anomaly ( 717-720 млн лет) [см. также Fairchild et al., 2018; Lamothe et al., 2019]. 
терригенная махмутовская свита содержит тиллиты и прослои карбонатных пород; игонинская свита представлена в основном вулканогенными образованиями; шумская свита включает в себя кварцито-песчаники и сланцы, а также тиллитоподобные отложения [Козлов и др., 2011; Пучков и др., 2017]. Сообщается о находках венчающих карбонатов внутри аршинской серии [Горожанин и др., 2013].

Как отмечалось выше, по цирконам вулканитов игонинской свиты были получены SIMS-датировки $707 \pm 2,3$ и $732 \pm 1,7$ млн лет [Краснобаев и др., 2012], а литохимические параметры магматических пород позволили отнести их к внутриконтинентальным рифтогенным образованиям [Маслов и др., 2018б]. В соответствии с указанными значениями абсолютного возраста, тиллиты махмутовской свиты были сопоставлены с отложениями гляциопериода Кайгас ${ }^{2}$, а сама аршинская серия - с криогением МСШ [Пучков и др., 2014; Puchkov et al., 2014] (до 2015 года нижняя граница криогения проводилась на уровне 850 млн лет).

Маловероятно, что обе приведённые датировки отражают продолжительное время формирования основного тела игонинской свиты. Эффузивные породы в составе свиты считаются комагматичными образованиями с гранитами Барангуловского массива [Краснобаев и др., 2012] (как и вулканиты машакской свиты среднего рифея и граниты Бердяушского массива, а также многие другие ассоциирующие с рифтами крупные магматические комплексы [Ernst et al., 2006; Ронкин и др., 2016, 2020]). Возраст Барангуловского массива оценивался примерно как $725 \pm 5$ млн лет (SHRIMP) [Краснобаев и др., 2007]. Однако полученные недавно результаты TIMS-датирования цирконов [Ронкин и др., 2020] несколько «омолаживают» этот массив до $673 \pm 39$ млн лет. Учитывая, что и вулканиты игонинской свиты могли сформироваться примерно в то же время (ранее для них получена датировка $677 \pm 31$ млн лет [Горожанин, 1995], а также дополнительные датировки по цирконам с возрастом менее 690 млн лет [Краснобаев и др., 2019]), возможно, тиллиты махмутовской свиты всё же отвечают оледенению Стёрт.

Прямые данные о возрасте криволукской свиты, а также кургашлинской и байназаровской свит Криволукской синклинали немногочисленны. Отмечается, что криволукская свита залегает на верхнерифейских карбонатах с выраженным перерывом и имеет резкий контакт с вышележащей кургашлинской свитой [Пучков и др., 2014; Ларионов и др., 2015]. По литологическим признакам криволукскую свиту коррелируют с аршинской серией [Козлов и др., 2011; Пучков и др., 2014], к которой она и была в последнее время отнесена [Пучков и др., 2017], тогда как кургашлинско-байназаровская последовательность несёт признаки марино-гляциального генезиса и по составу слагающих её отложений близка к урюкской свите ашинской серии [Горожанин, Канипова, 2017 и др.]. Н.М. Чумаков [2015] считает кургашлинскую свиту одновозрастной с аршинскими тиллитами, он же указывает на присутствие прослоев и линз доломитов в её составе [Чумаков и др., 2013]. В то же время, верхний возрастной предел криволукской свиты, на основе радиоизотопных измерений $\mathrm{Rb}-\mathrm{Sr}$ возраста малых интрузий в ней,

${ }^{2}$ Предполагается, что это оледенение могло произойти на уровне 750 \pm 15 млн лет (или, по другим оценкам, 730-750 млн лет) [Frimmel et al., 1996; Xu et al., 2009; Hofmann et al., 2015; MacLennan et al., 2020], но его глобальный характер оспаривается [Rooney et al., 2015 и др.]. 
составляет примерно 660 млн лет [Генина и др., 2015 и ссылки в этой работе]. По наблюдениям А.В. Маслова [2000], за пределами Криволукской синклинали (автотрасса Кага - Верхний Авзян) тиллитсодержащие отложения, сопоставляемые с кургашлинской свитой, выполняют глубокий эрозионный врез, залегая на карбонатах миньярской свиты.

\section{Ашинская серия}

Наиболее дискуссионным объектом в пределах БМА является терригенная ашинская серия. В отношении неё взгляды исследователей разнятся как по вопросам возраста, так и объёма. Чаще всего в ашинскую серию включаются все доордовикские свиты западного крыла БМА, залегающие выше укской свиты: бакеевская, толпаровская (в т.ч. калыштинские слои), суировская, урюкская, басинская, куккараукская (ранее куркураукская) и зиганская [Беккер, 1968, 1975, 1988; Козлов, 1982; Пучков и др., 2014, 2017; Кузнецов и др., 2012, 2019; Горожанин и др., 2019]. В последнее время некоторые исследователи надстраивают указанную последовательность малоямантауской свитой [Беккер, 2010; Разумовский, 2018]; при этом, несмотря на высокое фациальное сходство свиты с басинско-зиганскими отложениями, находки в ней ихнофоссилий кембрийского облика не позволили Ю.Р. Беккеру [2010] отнести её к ашинской серии венда. Толпаровская и суировская свиты имеют локальное распространение в разных тектонических структурах, а урюкская свита залегает на бакеевской с перерывом [Маслов и др., 2001] ${ }^{3}$. Соответственно, рядом авторов ашинская серия принимается только в объёме от подошвы урюкской свиты [Kolesnikov et al., 2015].

Более остро стоит вопрос о времени образования данной серии, которому посвящены многочисленные публикации начиная с 1931 года. Очевидно лишь то, что возраст её подразделений различен и гипотетически лежит в диапазоне от позднего рифея (если ассоциировать толпаровско-суировскую последовательность с гляциоэпохой Стёрт) до кембрия (если признать, что фосфатный детрит, обнаруженный в куккараукской свите, образовался при разрушении раковин беззамковых брахиопод [Кузнецов, Шацилло, 2011]). Самые молодые детритовые цирконы в толпаровской свите имеют возраст $889 \pm 21$ млн лет [Кузнецов и др., 2019], в басинской и куккараукской - соответственно $705 \pm 12$ и $617 \pm$ 10 млн лет. В куккараукской свите присутствуют также гальки гранитов с возрастом 530550 млн лет (но эта датировка получена по полевым шпатам и считается «омоложенной»), а также $714 \pm 6$ млн лет [Glasmacher et al., 1999; Сергеева и др., 2019 и ссылки в этой работе].

Согласно последним исследованиям, глауконит в составе бакеевской свиты имеет возраст $642 \pm 9$ млн лет [Зайцева и др., 2019]. Указанные данные привлекаются для обоснования возраста нижней границы венда на уровне 640 млн лет, в связи с тем, что свита ранее относилась к венду [Беккер, 1975; Козлов, 1982]. Песчаная толпаровская и преимущественно глинистая суировская свиты считаются возрастными аналогами бакеевской свиты, но явных свидетельств этому нет. Толпаровская свита также сопоставляется с криволукской свитой восточного крыла БМА [Келлер и др., 1984]. Толпаровско-суировская последовательность заполняет эрозионную долину, врезанную в

3 Литолого-геохимические признаки отложений в целом свидетельствуют, что, по крайней мере в нижней (добасинской) части разреза перерывы в осадконакоплении играют весьма значительную роль [Маслов, 2020]. 
отложения верхнего рифея на глубину более 1 км и содержит признаки мариногляциального генезиса [Келлер и др., 1984; Горожанин и др., 2019]. Глауконит суировской свиты датирован Rb-Sr методом с результатом $638 \pm 70$ млн лет [Горожанин, 1995]. В верхней части этой свиты обнаружен прослой венчающих доломитов, который по изотопному составу кислорода и углерода отличается от кэп-карбонатов внутри аршинской серии [Горожанин и др., 2012, 2013].

Урюкская свита пока осталась неохваченной исследованиями U-Pb систематики детритовых цирконов. По ней имеются лишь малонадёжные сведения о калий-аргоновом возрасте глауконита - 569 и 582 млн лет [Гаррис, 1977; Стратотип, 1983]. В свите не обнаружены остатки вендской макробиоты [Беккер, 2013; Kolesnikov et al., 2015, Разумовский, 2018], и по причине того, что они отсутствуют и в нижележащих отложениях, нет оснований считать, что свита моложе 570 млн лет [в соответствии с Pu et al., 2016]. Урюкская свита состоит из двух разнородных толщ / пачек, нижняя из которых, вероятно, формировалась в условиях холодного климата и содержит подводно-оползневые складки [Козлов, 1982; Маслов и др., 2000; Горожанин и др., 2019]. Для верхней пачки с «многоэтажной» косой слоистостью в разрезе вблизи г. Усть-Катав Д.В. Гражданкин предполагает аллювиально-дельтовый генезис. Упомянутые признаки не противоречат друг другу и не исключают сходные обстановки осадконакопления, но возможно, что к урюкской свите исследователи относят различные по генезису толщи. Данные о характере контакта свиты с подстилающими отложениями противоречивы [Маслов и др., 2001; Горожанин и др., 2019]. Граница урюкской свиты с басинской также проведена условно [Беккер, 1968; Разумовский, 2018]. Состав породообразующих компонентов в песчаниках этих свит существенно различается (песчаники урюкской свиты близки по составу к аркозам, басинской - к грауваккам), что может указывать на существование между этими геологическими телами перерыва в осадконакоплении [Маслов, 2020]. В то же время, литологические критерии, позволяющие установить реальную границу свит (её положение в разрезе и на местности), отсутствуют (хоть и некоторые характеристические особенности отложений приведены также в работах В.И. Козлова [1982] и А. Виллнера с соавторами [Willner et al., 2001]).

Стратиграфическим «якорем» для ашинской серии являются две датировки цирконов из пеплового прослоя в разрезе возле г. Усть-Катав: 548,2 7,6 млн лет [Гражданкин и др., 2011] и 547,6 $\pm 3,8$ млн лет [Levashova et al., 2013]. В этой местности отсутствуют куккараукские конгломераты, отделяющие басинские отложения от сходных по литологии зиганских, что определило существование нескольких точек зрения на стратиграфическую приуроченность басинско-куккараукско-зиганской последовательности. 1. По мнению Д.В. Гражданкина и А.В. Колесникова с соавторами, данные датировки принадлежат басинской свите, а куккараукско-зиганские отложения на этой территории были размыты в преддевонское время [Kolesnikov et al., 2015]. Tакое предположение подкрепляется обнаружением фосфатного детрита, интерпретируемого как обломки раковин беззамковых брахиопод, в куккараукской свите на руч. Куккараук [Кузнецов, Шацилло, 2011]; ранее имели место сообщения о находках в ашинской серии сколекодонтов и других палеозойских (?) ископаемых [Чибрикова, Олли, 2008; и др.]. Однако до сих пор не опубликовано ни одной работы, в которой присутствовали бы иллюстрации с однозначно диагностированными палеозойскими формами. Кроме того, Ю.Р. Беккер [2013, стр. 54] указывал на находки ихнофоссилий Treptichnus pedum (индикатора подошвы кембрия МСШ) в верхней части басинской свиты, но подобная трактовка экземпляров его коллекции в настоящее время оспаривается [Иванцов, Закревская, 2018]. 2. Распространены взгляды, что в позднем венде обломочный материал в осадочный бассейн поступал в основном с востока [Беккер, 1968, 1988; Пучков, 2010; 
Кузнецов и др., 2012; Краснобаев и др., 2019; Маслов, 2020], в связи с этим куккараукская свита выклинивается в западном направлении, и в усть-катавском разрезе уровень с пеплами, по-видимому, представлен зиганской свитой [Levashova et al., 2013; Разумовский, 2018 и др.]. В других структурах БМА пепловые прослои также характерны именно для зиганской свиты [Сергеева и др., 2019].

Таксономический состав остатков вендской биоты в разрезе ашинской серии в окрестностях г. Усть-Катав позволяет коррелировать рассматриваемые отложения с котлинским региоярусом венда [Гражданкин и др., 2011; Kolesnikov et al., 2015], рамки которого оцениваются в 550-540 млн лет [Grazhdankin, 2014]. Таким образом, если эти фоссилии принадлежат басинской свите, то возраст вышележащей части ашинской серии с высокой степенью вероятности может быть кембрийским, а если зиганской - значит басинско-куккараукская последовательность древнее 548 млн лет. Однако в ашинской серии не обнаружена типичная биота беломорского региояруса (559-550 млн лет) [Гражданкин и др., 2011; Grazhdankin, 2014], что заставляет либо относить к котлинскому региоярусу также басинскую и куккараукскую свиты [Kolesnikov et al., 2015], либо предполагать достаточно длительный перерыв (перерывы?) внутри серии [Гражданкин и др., 2011].

Недавно опубликованные результаты датирования цирконов из пепловых прослоев в ашинской серии свидетельствуют, что отложения басинской свиты накапливались уже $573 \pm 2,3$ млн лет назад [Разумовский и др., 2020]. Но на сегодня нет полной уверенности, что это действительно так, поскольку принадлежность изученных туфов именно басинской свите, на наш взгляд, не вполне обоснована. Проба была отобрана из обнажения вдоль строящейся дороги Стерлитамак-Белорецк [Разумовский и др., 2020] на достаточно низком стратиграфическом уровне (согласно графике, представленной в обсуждаемой работе), из полосы нерасчленённых отложений ашинской серии [Государственная..., 2013]. Подробные послойные описания и результаты литогеохимических исследований данного разреза пока отсутствуют. В то же время, мощность басинской свиты, согласно классическим работам [Беккер, 1968, 2010; Козлов, 1982; Маслов и др., 2001], не превышает 900-1050 м. Кроме того, в этом фрагменте разреза ашинской серии присутствуют необнажённые интервалы. Таким образом, точка отбора пробы может находиться в толще, подстилающей басинскую свиту (в урюкской свите?), что, в сочетании с литологически неопределённым уровнем её нижней границы, вполне вероятно (как уже отмечалось, урюкская свита, скорее всего, отделена от вышележащих отложений перерывом и недостаточно хорошо изучена). С другой стороны, все местонахождения эдиакарской макробиоты в басинской свите открыты пока только в её верхней подсвите [Беккер, 1988; Разумовский, 2018]. Если будет доказана принадлежность комплекса этой биоты к редкинскому региоярусу венда, то нижняя граница басинской свиты действительно должна быть древнее 570 млн лет, а стратиграфический диапазон надурюкской части ашинской серии окажется значительно шире, чем предполагали многие исследователи.

\section{НОВЫЙ ВАРИАНТ СТРАТИГРАФИЧЕСКОГО РАСЧЛЕНЕНИЯ ВЕРХНЕРИФЕЙСКО-ВЕНДСКИХ ОТЛОЖЕНИЙ БМА}

Привязка рубежей общих стратиграфических подразделений докембрия $\mathrm{K}$ несогласиям и началам крупных тектонических циклов показала свою бесперспективность при корреляциях удалённых разрезов. Оценки абсолютного возраста, известные для стратонов верхнего докембрия, также не могут являться диагностическим признаком для 
установления границ этих подразделений на местности. В основе стратиграфической шкалы докембрия, как и шкалы фанерозоя, должна лежать хронологическая последовательность глобальных и прослеживаемых геологических событий. При этом целесообразно рассматривать рифей в качестве эратемы (эры), состоящей из четырёх систем (периодов) - нижнего, среднего, верхнего и терминального рифея (бурзяния, юрматиния, каратавия и аршиния соответственно) [Пучков и др., 2017], а также утвердить в шкале вендскую эратему (эру), по объёму равную вендской системе (периоду). В качестве событий-критериев, определяющих нижнюю границу верхнего рифея (1), терминального рифея (2) и венда (3), могут рассматриваться соответственно: 1) первое появление в разрезе микрофоссилий Trachyhystrichosphaera sp.; 2) подошва первых ледниковых отложений, образовавшихся в гляциопериоде Стёрт (что приблизительно будет соответствовать нижней границе криогения МСШ); 3) подошва над-Гаскьерских отложений (в том числе венчающих карбонатов), или вариации изотопного состава $\mathrm{Sr}$ и $\mathrm{C}$ на уровне 580 млн лет. Основываясь на обозначенных выше и обсуждаемых в работе [Дуб, в печати] предложениях по совершенствованию ОСШ докембрия, рассмотрим новый вариант стратиграфического расчленения верхнерифейско-вендских отложений БМА и возможности его корреляции с МСШ (рис. 1 и 2).

\section{Средний и верхний рифей}

С учётом имеющийся информации по изменчивому литологическому составу, распределению микрофоссилий и детритовых цирконов (свидетельствующих о значительных изменениях источников сноса и потенциальном существовании перерывов) в зильмердакской свите [Маслов и др., 2001, 2014, 2018а; Сергеев и др., 2010; Романюк и др., 2013; и др.], мы считаем необходимым (1) повысить её ранг до серии (а подсвит - до свит) и, (2) руководствуясь критерием первого появления остатков Trachyhystrichosphaera aimika, установить нижнюю границу верхнего рифея (каратавия) ОСШ на уровне находки представителей этого индекс-таксона в бедерышинской свите ${ }^{4}$. Такие изменения оправданы с точки зрения разницы в литологии между почти исключительно терригенной зильмердакской и вышележащей терригенно-карбонатной катавско-укской последовательностью. Кроме того, они сохраняют неизменной концепцию отнесения каратауской серии (но только в объёме катавско-укских отложений) к верхнему рифею. Подобные «реформы» правомерны также для более древних свит стратотипа рифея, имеющих пёстрый литолого-фациальный состав (согласно Стратиграфическому кодексу [2019, стр. 26-27], свита должна отличаться от выше- и нижележащих отложений в первую очередь составом пород, включение резко разнофациальных отложений в одну свиту не рекомендуется).

Предположение об отрывочном характере геологической летописи позднего рифея в стратотипе [Подковыров и др., 1998] не объясняет кардинального различия между Сизотопными характеристиками каратауской серии и данными по наиболее полным разрезам тония других регионов: значения $\delta^{13} \mathrm{C}$ в карбонатных отложениях Южного Урала

${ }^{4}$ Вопрос о пересмотре данной границы может возникнуть вновь в результате биостратиграфических исследований верхних уровней авзянской свиты. 
существенно ниже [Подковыров и др., 1998, Кузнецов и др., 2006; Kuznetsov et al., 2017]. В отложениях тония севера Канады, востока Шпицбергена и Эфиопии в интервале 850-740 млн лет изотопный состав углерода варьирует преимущественно в диапазоне от 2 до 8\%, опускаясь до -4\%о только на уровне единичных отрицательных экскурсов [Halverson et al., 2010; Swanson-Hysell et al., 2015; Cox et al., 2016]. В стратотипе верхнего рифея значения $\delta^{13} \mathrm{C}_{\text {карб }}$ в основном лежат в пределах от -2 до $\sim 4$ (с экскурсом до $\sim 6 \%$ в верхах миньярской свиты) [Подковыров и др., 1998; Кузнецов и др., 2006; Kuznetsov et al., 2017] ${ }^{5}$, то есть магнитуды вековых вариаций изотопного состава углерода сходны. Сопоставление кривой вариации величины $\delta^{13} \mathrm{C}$ в карбонатах каратауской серии [Kuznetsov et al., 2017] и кривых, полученных для отложений тония других бассейнов и лучше откалиброванных по абсолютному возрасту [например, Swanson-Hysell et al., 2015], позволили прийти к выводу, что вся инзерско(катавско?)-миньярская последовательность, скорее всего, сформировалась в интервале 840(850?)-820 млн лет (см. рис. 1), что несколько отличается от предыдущих оценок [Kuznetsov et al., 2017] (при этом, возраст катавской свиты по-прежнему остаётся дискуссионным). По всей видимости, бассейн пассивной окраины Балтики в тонии характеризовался специфическими гидрохимическими условиями, но сообщался с Мировым океаном. В частности, относительно низкие значения величин $\delta^{13} \mathrm{C}$ в карбонатах каратауской серии могут быть объяснены с позиций гипотезы о существовании в неопротерозойских океанах резервуара растворённого органического углерода (DOC) [Rothman et al., 2003; Lowenstein et al., 2014].

K сожалению, глауконит является ненадёжным минералом для определения абсолютного возраста пород, испытавших эпигенетические преобразования (особенно приуроченных к складчато-надвиговым поясам). На это указывает увеличивающееся с каждым годом число публикаций, посвящённых обнаружению «омоложенного» (по сравнению с реальным возрастом отложений) глауконита, в том числе изученного различными физико-химическими методами [например, Горохов и др., 1997; 2019; Зайцева и др., 2018; 2019; Ивановская и др., 2019]. В своё время, Б.М. Келлер, опираясь на опыт предшественников, не рекомендовал пользоваться определениями возраста глауконита (KAr) до тех пор, пока они не будут подтверждены другими радиоизотопными методами [Стратотип..., 1983]. С. Боуринг с соавторами приводили доказательства того, что рубидий-стронциевый метод определения возраста пород не очень надёжен [Bowring et al., 1993]. С учётом вышеизложенного, имеющиеся датировки по глаукониту в каратауской серии нельзя рассматривать в качестве реперов. Данные $\mathrm{Sr}-$ и С-изотопной хемостратиграфии свидетельствуют, что осадки укской свиты возникли в интервале 780740 млн лет, вследствие чего её следует относить к тонию / верхнему рифею. Однако мы вынуждены признать, что для этого интервала времени пока не так много достоверных данных об изотопном составе стронция в морской воде [Derry et al., 1992; Miller et al., 2009; Park et al., 2019, Zhou et al., 2020]. Если другими независимыми методами возраст укской свиты будет определён в этих пределах, то её отложения могут оказаться мировым

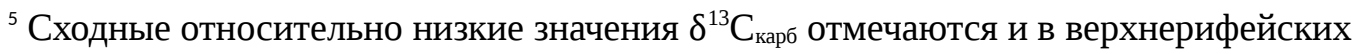
отложениях Северного Урала [Покровский, Чумаков, 2009], которые накапливались в пределах той же эпиконтинентальной карбонатной платформы [Маслов и др., 2002]. 
эталоном для указанного отрезка геологической летописи. Публикация результатов датирования детритовых цирконов из нижнеукской подсвиты, возможно, позволит уточнить нижнюю границу диапазона вероятного возраста.

\section{Терминальный рифей и венд}

При установлении нижней границы терминального рифея (аршиния) по появлению ледниковых отложений гляциопериода Стёрт ${ }^{6}$, а верхней - по кровле тиллитов Гаскье, во всех дальнейших построениях нужно учитывать, что стратиграфический объём аршиния как системы - скорее всего больше диапазона аршинской серии, а его основание не совпадает с подошвой последней (подобная участь постигла многие местные подразделения, ставшие впоследствии общими). Предварительно, эталоном нижней границы аршиния ОСШ может служить подошва первых однозначно диагностируемых тиллитов махмутовской свиты. Нижележащую байнасскую свиту, таким образом, следует включить в состав каратавия ОСШ (по данным В.И. Козлова с соавторами [2011], контакт между свитами согласный). Для подтверждения или опровержения варианта корреляции тиллитов махмутовской свиты с оледенением Стёрт необходимо датировать цирконы синседиментационных вулканитов игонинской свиты методом CA-ID-TIMS (но гарантий эффективности таких исследований нет, т.к. первые шаги в этом направлении свидетельствуют о чрезвычайно широком диапазоне возрастов цирконов [Краснобаев и др., 2012, 2019]).

Сведения по толпаровско-суировской и кургашлинско-байназаровской последовательностям, выполняющим врезанные долины и несущим признаками мариногляциального генезиса, заставляют предполагать их приуроченность к событию Марино. Но недавно было показано, что это оледенение не сопровождалось катастрофическим падением уровня Мирового океана, а наиболее крупные эрозионные формы рельефа, часто открывавшиеся в древние рифты, в других регионах мира были в основном приурочены к оледенению Стёрт [Bechstädt et al., 2018; Williams, Gostin, 2019; Mitchell et al., 2019]. По этой причине полноценные корреляции для аршиния БМА с МСШ пока преждевременны. Возможно, образование врезанных долин происходило во время оледенения Стёрт, а их осадочное заполнение формировалось позднее, в несколько этапов, при повышении уровня моря.

Наиболее остро на данный момент стоят вопросы взаимоотношения аршинской и ашинской серий. В связи с тем, что серия - это местное стратиграфическое подразделение, а система (или ярус) - общее, для включения свиты в ту или иную серию главное значение должны иметь её литологические характеристики, а не возраст. Соответственно, границу между сериями в первую очередь следует определять непосредственно по смене литогеохимических параметров отложений.

Одним из хорошо петрографически выраженных уровней верхнего докембрия БМА считается урюкская свита (и литологически сходные с ней отложения на восточном крыле БМА) [Беккер, 1975; Маслов, 2000; Kolesnikov et al., 2015; Горожанин, Канипова, 2017],

${ }^{6}$ Данный признак является не самым удачным (нет уверенности, что наступление оледенения было одновременным), опыт выбора GSSP подошвы криогения показывает, что предпочтение может быть отдано вариациям изотопного состава С и $\mathrm{Sr}$ в подстилающих тиллиты отложениях [Shields et al., 2018]; но, несомненно, лучше всего придерживаться единого с МСШ критерия. 
поэтому подстилающие её фациально-различные отложения, лежащие над каратауской серией (на западе это бакеевская свита и толпаровско-суировская последовательность), возможно, следует отнести к аршинской серии.

Однозначно решить вопрос о такой корреляции пока не позволяют имеющиеся предположения о постепенном переходе между суировской и урюкской свитами [Горожанин и др., 2019]. Несмотря на некоторые различия в литологии между урюкской и басинской свитами, обе они традиционно причисляются к ашинской серии [Беккер, 1968]. Байназаровская свита считается аналогом урюкской, соответственно она тоже принадлежит ашинской серии. В серию следует включать и кургашлинскую свиту, если она действительно связана с байназаровской постепенным переходом [Чумаков, 1998; Пучков и др., 2014; Горожанин, Канипова, 2017]. Для подтверждения или опровержения тезиса, что граница между аршинской и ашинской сериями должна проводиться в подошве урюкской свиты, необходимо привлечение надёжных петрографических и литогеохимических данных ${ }^{7}$.

Сходным образом, если специальными исследованиями подтвердится предполагаемое сходство литологических и геохимических характеристик басинскозиганской последовательности и малоямантауской свиты кембрия (?), то последняя также должна быть включена в ашинскую серию.

Что касается нижней границы венда, связываемой нами с окончанием гляциопериода Гаскье, то имеющейся к настоящему моменту информации недостаточно для её надёжного установления в разрезах БМА. Скорее всего, она совпадает с перерывом в осадконакоплении. Необходимы детальные исследования урюкской свиты и нижнебасинской подсвиты (в первую очередь изучение U-Pb систематики детритовых цирконов и микрофоссилий). Похоже обстоит ситуация и с нижней границей кембрия исследование ихнофоссилий и дальнейший поиск скелетных остатков в ашинской серии, вероятно, позволят решить этот вопрос.

Можно утверждать, что в верхнерифейской геологической летописи БМА значительную роль играют перерывы, тогда как время накопления сохранившихся отложений было в целом значительно меньшим. Такой характер разреза объясняется особенностями седиментации на пассивных континентальных окраинах, которая в первую очередь зависит от колебаний относительного уровня моря [Burchette, Wright, 1992; Catuneanu, 2006]. Позднее рельеф рассматриваемой территории оказался осложнен рифтовыми впадинами и врезанными долинами, благоприятствующими аккумуляции и частичному сохранению отложений терминального рифея. Стратиграфические перерывы, предшествующие накоплению вендских толщ и характерные для большей площади БМА, были связаны с глобальными оледенениями и, возможно, с коллизионными процессами.

\section{ЗАКЛЮЧЕНИЕ}

1. Зильмердакскую свиту БМА рекомендовано перевести в ранг серии, а бирьянскую, нугушскую, лемезинскую и бедерышинскую подсвиты - в ранг свит. Принципиальные отличия в литологических характеристиках, полученные недавно свидетельства о различных источниках сноса, предположения о наличии перерывов на ряде уровней и данные сопоставительного анализа мощностей являются предпосылками для этих изменений. Предлагаемые преобразования рациональны и с точки зрения различий в литологии между исключительно терригенной зильмердакской и

${ }^{7}$ Несмотря на то, что границы местных стратиграфических подразделений не должны существенно пересматриваться, в связи с получением новой информации по урюкской свите, могут возникнуть аргументы в пользу и её отнесения к аршинской серии. 
вышележащей терригенно-карбонатной катавско-укской последовательностью. Закономерны аналогичные изменения в стратиграфических схемах для нижнего и среднего рифея.

2. Если в качестве критерия подошвы верхнего рифея будет утверждён уровень первого появления микрофоссилий Trachyhystrichosphaera sp., то формально граница среднего и верхнего рифея в стратотипе должна проводиться вблизи основания бедерышинской свиты, ниже которой остатки этих акантоморфных акритарх в разрезе (пока?) не обнаружены. Предполагаемая корреляция зильмердакской серии с ишеримской свитой Северного Урала с возрастом от 1150 до $1079 \pm 41$ млн лет подтверждает правомерность внесения корректировок в региональную стратиграфическую схему. С другой стороны, возраст отложений, в которых найдены индекс-таксоны Trachyhystrichosphaera sp., может достигать 1130 млн лет [Beghin et al., 2017]. Но, судя по датировкам детритовых цирконов в бирьянской свите, зильмердакская серия не могла начать формироваться ранее 1100-1050 млн лет назад (для большей точности требуется датирование самой молодой популяции детритовых цирконов бирьянской свиты CA-IDTIMS методом). Выявленное противоречие объясняется непредставительностью рубежа $\mathrm{RF}_{2} / \mathrm{RF}_{3}$ в стратотипе рифея. Очевидно, что разрезы на Южном Урале не могут претендовать на роль эталонов границ между системами рифея в докембрии, соответственно необходим поиск таковых в других регионах.

3. Данные Sr- и C-изотопной хемостратиграфии указывают на то, что отложения инзерской и миньярской свит, скорее всего, накапливались в интервале 840-820 млн лет, а укской - 780-740 млн лет. Несомненно, для укской свиты реальная продолжительность осадконакопления была существенно меньше; возможно, дальнейшие исследования позволят уточнить нижний предел отмеченного интервала.

4. Бакеевскую свиту, а также толпаровско-суировскую последовательность (частично или полностью), вероятнее всего, следует отнести к аршинской серии и рассматривать как модификации последней на западном крыле БМА. Но внесение изменений в стратиграфические схемы уместно только после надёжного обоснования сходства отложений западного и восточного крыла по литолого-геохимическим характеристикам, а также их отличий от перекрывающих отложений.

5. В соответствии с представленными нами ранее предложениями по совершенствованию ОСШ верхнего докембрия, махмутовская, игонинская, шумская кургашлинская, бакеевская свита, а также толпаровско-суировская последовательность, по-видимому, принадлежат аршинской системе (=терминальному рифею, в границах 717-580 млн лет) рифейской эратемы. К этому же стратиграфическому подразделению с долей вероятности могут быть отнесены урюкская и байназаровская свиты, а также, возможно, криволукская свита.

Автор признателен М.Т. Крупенину, А.В. Маслову, Д.В. Гражданкину и В.Н. Пучкову за продуктивное обсуждение затронутых в статье проблем. А.В. Маслов провёл критический анализ первого варианта рукописи, А.Б. Кузнецов и Д.В. Гражданкин высказали ценные замечания по существу изложенного материала, что позволило усовершенствовать данную работу. Исследования выполнены при финансовой поддержке РФФИ (грант № 18-05-00062) и в рамках темы АААA-A18-118053090044-1 госзадания ИГГ УрО РАН.

\section{ЛИТЕРАТУРА}


Беккер Ю.Р. Возраст и последовательность напластования отложений верхней части каратауской серии Южного Урала // Изв. АН СССР. Сер. геол., 1961, №9, с. 49-60.

Беккер Ю.P. Геологический потенциал древних ихнофоссилий в стратотипе позднего докембрия Южного Урала // Региональная геология и металлогения, 2010, № 43, с. $18-35$.

Беккер Ю.Р. Ихнофоссилии - новый палеонтологический объект в стратотипе позднего докембрия Урала // Литосфера, 2013, № 1, с. 52-80.

Беккер Ю.Р. Молассы докембрия. Л., Недра, 1988, 288 с.

Беккер Ю.Р. Позднедокембрийская моласса Южного Урала. Л., Недра, 1968, 160 с.

Беккер Ю.Р. О выделении бакеевских отложений в стратотипическом разрезе рифея // Изв. АН СССР. Сер. геол., 1975, № 6, с. 125-129.

Вейс А.Ф., Козлов В.И., Сергеева Н.Д., Воробьева Н.Г. Микрофоссилии типового разреза верхнего рифея (каратавская серия Южного Урала) // Стратиграфия. Геол. корреляция, 2003, т. 11, № 6, с. 19-44.

Гаррис М.А. Этапы магматизма и метаморфизма в доюрской истории Урала и Приуралья. М., Наука, 1977, 295 с.

Генина Л.А., Ларионов Н.Н., Захаров А.А. Интрузивный магматизм и метаморфизм // Государственная геологическая карта Российской федерации. Масштаб 1:200 000. Издание второе. Серия Южно-Уральская. Лист N-40-ХХП - Тукан. Объяснительная записка. М., МФ ВСЕГЕИ, 2015.

Горожанин В.М. Рубидий-стронциевый изотопный метод в решении проблем геологии Южного Урала. Автореф. дис... канд. геол.-мин. наук. Екатеринбург, 1995, 23 с.

Горожанин В.М., Канипова 3.А. Литологические индикаторы мариногляциального генезиса отложений байназаровской свиты венда (Криволукский грабен Башкирского мегантиклинория, Южный Урал) // Геологический сборник № 13 ИГ УНЦ РАН. СПб, Своё издательство, 2017, с. 34-43.

Горожанин В.М., Кутявин Э.П. Рубидий-стронциевое датирование глауконита укской свиты // Докембрий и палеозой Южного Урала. Уфа, БФАН СССР, 1986, с. 60-63.

Горожанин В.М., Мичурин С.В., Биктимерова 3.P. Изотопно-геохимические особенности «венчающих доломитов» аршинской свиты (Южный Урал) // Геология. Известия Отделения наук о Земле и природных ресурсов АН РБ, 2013, № 19, с. 61-67.

Горожанин В.М., Мичурин С.В., Биктимерова 3.Р. Изотопно-геохимические особенности «венчающих доломитов» в вендских отложениях Южного Урала // Геология. Известия Отделения наук о Земле и природных ресурсов АН РБ, 2012, № 18, с. 42-52.

Горожанин В.М., Мичурин С.В., Войкина 3.А., Шарипова А.А., Биктимерова 3.P., Султанова А.Г. Марино-гляциальные отложения в Толпаровском разрезе верхнего докембрия (реки Зилим и Малый Толпар) // Геологический вестник, 2019, № 3, с. 69-92.

Горохов И.М., Зайцева Т.С., Кузнецов А.Б., Овчинникова Г.В., Аракелянц М.М., Ковач В.П., Константинова Г.В., Турченко Т.Л., Васильева И.М. Изотопная систематика и возраст аутигенных минералов в аргиллитах верхнерифейской инзерской свиты Южного Урала // Стратиграфия. Геол. корреляция, 2019, т. 27, № 2, с. 3-30.

Горохов И.М., Яковлева О.В., Семихатов М.А., Мельников Н.Н., Ивановская Т.А., Кутявин Э.П. «Омоложенный» Al-глауконит в пограничных венд-кембрийских отложениях Подльского Приднестровья (Украина): Rb-Sr и K-Ar систематика и ${ }^{57} \mathrm{Fe}$ мессбауэровские спектры // Литология и полез. Ископаемые, 1997, № 6, с. 616-635.

Горяинова О.П., Фалькова Э.А. Древние свиты западного склона Южного Урала // Бюлл. МОИП. Отд. геол., 1937, т. XV, вып. 3, с. 242-274. 
Государственная геологическая карта РФ м-ба 1:1000000 (третье поколение). Лист N-40 - Уфа. Картографическая фабрика ВСЕГЕИ, 2013.

Гражданкин Д.В., Марусин В.В., Меерт Дж., Крупенин М.Т., Маслов А.В. Котлинский горизонт на Южном Урале // ДАН, 2011, т. 440, № 2, с. 201-206.

Гражданкин Д.В., Маслов А.В. Место венда в международной стратиграфической шкале // Геология и геофизика, 2015, т. 56, № 4, с. 703-717.

Дуб С.А. Проблемы общей стратиграфической шкалы верхнего докембрия и предложения по её совершенствованию // Литосфера, в печати.

Дуб С.А., Гражданкин Д.В., Бобков Н.И. Molar tooth structures в укской свите (верхний рифей, Южный Урал) и их стратиграфическое значение // Литология и я: от идеи до выводов. Материалы 3-й Всерос. школы студентов, аспирантов, молодых ученых и специалистов по литологии, 2018, с. 72-74.

Зайцева Т.С., Горохов И.М., Ивановская Т.А., Семихатов М.А., Кузнецов А.Б., Мельников Н.Н., Аракелянц М.М., Яковлева О.В. Мессбауэровские характеристики, минералогия и изотопный возраст (Rb-Sr, K-Ar) верхнерифейских глауконитов укской свиты Южного Урала // Стратиграфия. Геол. корреляция, 2008, т. 16, №3, 3-25.

Зайцева Т.С., Горохов И.М., Семихатов М.А., Кузнецов А.Б., Ивановская Т.А., Константинова Г.В., Доржиева О.В. «Омоложенные» глобулярные слоистые силикаты в рифейских породах Оленекского поднятия: кристаллохимическая идентификация и геологическое значение датировок // Стратиграфия. Геол. корреляция, 2018, т. 26, № 5S, с. S3-S26.

Зайцева Т.С., Кузнецов А.Б., Горожанин В.М., Горохов И.М., Ивановская Т.А., Константинова Г.В. Основание венда на Южном Урале: Rb-Sr возраст глауконитов бакеевской свиты // Стратиграфия. Геол.корреляция, 2019, т. 27, № 5, с. 82-96.

Ивановская Т.А., Гептнер А.Р., Савичев А.Т., Зайцева Т.С., Горькова Н.В., Покровская Е.В. Глауконит в терригенно-карбонатных отложениях нижнего кембрия (Северная Сибирь, Оленекское поднятие) // Литология и полез. ископаемые, 2019, № 4, с. 295-317.

Иванцов А.Ю., Закревская М.А. Атлас макрофоссилий верхнего венда и нижнего кембрия (?) Среднего и Южного Урала // Макрофоссилии верхнего венда Восточной Европы. Средний и Южный Урал / ред. А.Ю. Иванцов. М., ПИН РАН, 2018, с. 32-71.

Келлер Б.М., Вейс А.Ф., Горожанин В.М. Толпаровский разрез верхнего докембрия (Южный Урал) // Изв. АН СССР. Сер. геол., 1984, № 9, с. 119-124.

Ковалев С.Г., Мичурин С.В., Маслов А.В., Шарипова А.А. Первые данные по геохимии редкоземельных элементов и платиноидов в породах золоторудного месторождения Улюк-Бар (Южный Урал) // Литосфера, 2020, т. 20, № 4, с. 573-591.

Козлов В.И. Верхний рифей и венд Южного Урала. М., Наука, 1982, 128 с.

Козлов В.И., Пучков В.Н., Краснобаев А.А., Нехорошева А.Г., Бушарина С.В. Аршиний - новый стратон рифея в стратотипических разрезах Южного Урала // Геологический сборник № 9 ИГ УНЦ РАН. Уфа, ДизайнПолиграфСервис, 2011, с. 52-56.

Крупенин М.Т. Минерагеническое и геодинамическое значение среднерифейского времени на западном склоне Южного Урала // ДАН, 2004, т. 399, № 4, с.503-505.

Кузнецов А.Б., Семихатов М.А., Горохов И.М. Возможности стронциевой изотопной хемостратиграфии в решении проблем стратиграфии верхнего протерозоя (рифея и венда) // Стратиграфия. Геол. корреляция, 2014, т. 22, №6, с. 3-25.

Кузнецов А.Б., Семихатов М.А., Горохов И.М. Стронциевая изотопная хемостратиграфия: основы метода и его современное состояние // Стратиграфия. Геол. корреляция, 2018, т. 26, № 4, с. 3-23. 
Кузнецов А.Б., Семихатов М.А., Горохов И.М., Мельников Н.Н., Константинова Г.В., Кутявин Э.П. Изотопный состав $\mathrm{Sr}$ в карбонатных породах каратавской серии Южного Урала и стандартная кривая вариаций отношения ${ }^{87} \mathrm{Sr} /{ }^{86} \mathrm{Sr}$ в позднерифейском океане // Стратиграфия. Геол. корреляция, 2003, т. 11, №5, с. 3-39.

Кузнецов А.Б., Семихатов М.А., Маслов А.В., Горохов И.М., Прасолов Э.М., Крупенин М.Т., Кислова И.В. Sr- и С-изотопная хемостратиграфия типового разреза верхнего рифея (Южный Урал): новые данные // Стратиграфия. Геол. корреляция, 2006, т. 14, № 6, с. 25-53.

Кузнецов Н.Б., Романюк Т.В., Маслов А.В., Горожанин В.М., Горожанина Е.Н., Каныгина Н.А., Дубенский А.С., Белоусова Е.А. Первые результаты U/Pb датирования детритовых цирконов из песчаников верхневендской бакеевской свиты Башкирского поднятия (Южный Урал) // Проблемы тектоники континентов и океанов. Материалы LI Тектонического совещания. Т. 1. М., ГЕОС, 2019, с. 305-309.

Кузнецов Н.Б., Романюк Т.В., Шацилло А.В., Орлов С.Ю., Голованова И.В., Данукалов К.Н., Ипатьева И.С. Первые результаты массового U/Pb-изотопного датирования (LA-ICP-MS) детритных цирконов из ашинской серии Южного Урала: палеогеографический и палеотектонический аспекты // ДАН, 2012, т. 447, №1, с. 73-79.

Кузнецов Н.Б., Шацилло А.В. Первые находки скелетных фоссилий в куккараукской свите ашинской серии Южного Урала и их значение для определения начала протоуральско-тиманской коллизии // ДАН, 2011, т. 440, № 3, с. 378-383.

Краснобаев А.А., Козлов В.И., Пучков В.Н., Ларионов А.Н., Нехорошева А.Г., Бережная Н.Г. Полигенно-полихронная цирконология и проблема возраста Барангуловского габбро-гранитного комплекса // ДАН, 2007, Т. 416, №2, с. 241-246.

Краснобаев А.А., Козлов В.И., Пучков В.Н., Сергеева Н.Д., Бушарина С.В. Новые данные по цирконовой геохронологии аршинских вулканитов (Южный Урал) // Литосфера, 2012, № 4, с. 127-140.

Краснобаев А.А., Пучков В.Н., Сергеева Н.Д., Бушарина С.В. Природа цирконовой кластики в песчаниках рифея и венда Южного Урала // Георесурсы, 2019, т. 21, №1, с. 15-25.

Ларионов Н.Н., Грановская Н.В., Нигматуллина А.М. Стратиграфия // Государственная геологическая карта Российской федерации. Масштаб 1:200 000. Издание второе. Серия Южно-Уральская. Лист N-40-ХХП - Тукан. Объяснительная записка. М., МФ ВСЕГЕИ, 2015.

Маслов А.В. Башкирский мегантиклинорий: позднерифейско-вендские перерывы и возможные трансформации систем питания бассейна тонкой алюмосиликокластикой // Литосфера, 2020, №4, с. 455-470.

Маслов А.В. Некоторые особенности ранневендской седиментации на Южном и Среднем Урале // Литология и полез. ископаемые, 2000, № 6, с. 624-639.

Маслов А.В., Абдуазимова 3.М., Карстен Л.А., Пучков В.Н. Первые находки меланоцириллиумов в эталонных разрезах рифея на Южном Урале // Состояние, проблемы и задачи геологического картирования областей развития докембрия на территории России. Тез. докл. Всерос. совещ. СПб., ИГГД РАН, 1994, с. 90.

Маслов А.В., Анфимов Л.В. Авзянская рудоносная свита среднего рифея Южного Урала (литостратиграфия, условия образования, минерагения). Екатеринбург, ИГГ УрО PAH, 2000, 132 c.

Маслов А.В., Ерохин Е.В., Гердес А., Ронкин Ю.Л., Иванов К.С. Первые результаты U-Pb LA-ICP-MS-изотопного датирования обломочных цирконов из аркозовых 
песчаников бирьянской подсвиты зильмердакской свиты верхнего рифея (Южный Урал) // ДАН, 2018а , т. 482, №5, с. 558-561.

Маслов А.В., Ковалев С.Г., Пучков В.Н., Сергеева Н.Д. Аршинская серия рифея Южного Урала: к вопросу о геодинамической природе породных ассоциаций // ДАН, 2018б, т. 480, № 1, с. 64-68.

Маслов А.В., Крупенин М.Т., Гареев Э.З., Анфимов Л.В. Рифей западного склона Южного Урала (классические разрезы, седименто- и литогенез, минерагения, геологические памятники природы). Екатеринбург, ИГГ УрО РАН, 2001, т. 1-4.

Маслов А.В., Оловянишников В.Г., Ишерская М.В. Рифей восточной, северовосточной и северной периферии Русской платформы и западной мегазоны Урала: литостратиграфия, условия формирования и типы осадочных последовательностей // Литосфера, 2002, № 2, с. 54-95.

Маслов А.В., Подковыров В.Н. Редокс-статус океана 2500-500 млн лет назад: современные представления // Литология и полез. ископаемые, 2018, № 3, с. 207-230.

Маслов А.В., Подковыров В.Н., Гареев Э.З., Ронкин Ю.Л. К вопросу о вкладе гренвильских событий в формирование наиболее полных осадочных последовательностей рифея Северной Евразии // Стратиграфия. Геол. корреляция, 2014, т. 22, № 2, с. 46-61.

Мичурин С.В., Шарипова А.А., Крупенин М.Т., Замятин Д.А., Мусина А.М., Попов В.А. Сульфидная минерализация, самородное золото и его геохимические связи в рифейских отложениях Авзянского рудного района (Южный Урал) // Литосфера, 2018, т. 18, № 1, с. 61-81.

Овчинникова Г.В., Васильева И.М., Семихатов М.А., Кузнецов А.Б., Горохов И.М., Гороховский Б.М., Левский Л.К. U-Pb-систематика карбонатных пород протерозоя: инзерская свита стратотипа верхнего рифея (Южный Урал) // Стратиграфия. Геол. корреляция, 1998, т. 6, № 4, с. 20-31.

Овчинникова Г.В., Васильева И.М., Семихатов М.А., Горохов И.М., Кузнецов А.Б., Гороховский Б.М., Левский Л.К. Возможности $\mathrm{Pb}-\mathrm{Pb}$ датирования карбонатных пород с открытыми U-Pb системами: миньярская свита стратотипа верхнего рифея, Южный Урал // Стратиграфия. Геол. корреляция, 2000, т. 8, № 6, с. 3-19.

Петров Г.А. К проблеме корреляции рифейских толщ Южного и Северного Урала // Ежегодник-2017. Тр. ИГГ УрО РАН, вып. 165, 2018, с. 67-70.

Петров Г.А., Ронкин Ю.Л., Маслов А.В. Проявление гренвильской орогении в рифейских толщах Северного Урала: термодинамические параметры метаморфизма и Sr$\mathrm{Nd}$ изотопные ограничения // ДАН, 2015, т. 462, № 6, с. 686-691.

Подковыров В.Н., Семихатов М.А., Кузнецов А.Б., Виноградов Д.П., Козлов В.И., Кислова И.В. Изотопный состав карбонатного углерода в стратотипе верхнего рифея (каратавская серия Южного Урала) // Стратиграфия. Геол. корреляция,1998, т. 6, №4, с. 3-19.

Покровский Б.Г., Чумаков Н.М. Изотопный состав углерода и кислорода в карбонатных породах деминской и низьвинской свит, верхний рифей Северного Урала // Стратиграфия. Геол. корреляция, 2009, т. 17, № 6, с. 105-108.

Постановления Межведомственного стратиграфического комитета и его постоянных комиссий. Вып. 39. СПб, 2010, 84 с.

Пучков В.Н. Геология Урала и Приуралья (актуальные вопросы стратиграфии, тектоники, геодинамики и металлогении). Уфа, ДизайнПолиграфСервис, 2010, 280 с.

Пучков В.Н., Сергеева Н.Д., Краснобаев А.А. Стратиграфическая схема стратотипа рифея Южного Урала // Геология. Известия Отделения наук о Земле и природных ресурсов АН РБ, 2017, № 23, с. 3-26. 
Пучков В.Н., Сергеева Н.Д., Ратов А.А. Отложения нижнего венда на Южном Урале: особенности состава и строения // Геологический сборник № 11 ИГ УНЦ РАН. Уфа, ДизайнПресс, 2014, с. 22-36.

Разумовский А.А. Венд Урала // Макрофоссилии верхнего венда Восточной Европы. Средний и Южный Урал / ред. А.Ю. Иванцов. М., ПИН РАН, 2018, с. 7-31.

Разумовский А.А., Новиков И.А., Рязанцев А.В., Рудько С.В., Кузнецов Н.Б., Яшунский Ю.В. Древнейшие вендские ископаемые Евразии: U-Pb-изотопный возраст басинской свиты (ашинская серия, Южный Урал) // ДАН, 2020, т. 495, № 2, с. 3-8.

Романюк Т.В., Маслов А.В., Кузнецов Н.Б., Белоусова Е.А., Ронкин Ю.Л., Крупенин М.Т., Горожанин В.М., Горожанина Е.Н., Серегина Е.С. Первые результаты $\mathrm{U} / \mathrm{Pb} \mathrm{LA}-\mathrm{ICP}-\mathrm{MS}$ датирования детритных цирконов из верхнерифейских песчаников Башкирского антиклинория (Южный Урал) // ДАН, 2013, т. 452, № 6, с. 642-645.

Ронкин Ю.Л., Тихомирова М., Маслов А.В. 1380 млн лет LIP Южного Урала: прецизионные U-Pb ID-TIMS ограничения // ДАН, 2016, т. 468, №6, с. 674-679.

Ронкин Ю.Л., Маслов А.В., Синдерн С. U-Pb (ID-TIMS) геохронологический метод и SIMS приемы датирования циркона: возможности и ограничения // Литосфера, 2020, №3, с. 411-431.

Рязанцев А.В., Кузнецов Н.Б., Дегтярев К.Е., Романюк Т.В., Толмачева Т.Ю., Белоусова Е.А. Реконструкция венд-кембрийской активной континентальной окраины на Южном Урале по результатам изучения детритовых цирконов из ордовикских терригенных пород // Геотектоника, 2019, т. 53, № 4, с. 43-59.

Семихатов М.А. Уточнение оценок изотопного возраста нижних границ верхнего рифея, венда, верхнего венда и кембрия // Дополнения к стратиграфическому кодексу России. СПб, ВСЕГЕИ, 2000, с. 95-107.

Сергеев В.Н. Окремненные микрофоссилии докембрия: природа, классификация и биостратиграфическое значение. М., Геос, 2006, 280 с.

Сергеев В.Н., Семихатов М.А., Федонкин М.А., Воробьева Н.Г. Основные этапы развития докембрийского органического мира: Сообщение 2. Поздний протерозой // Стратиграфия. Геол. корреляция, 2010, т. 18, № 6, с. 3-34.

Сергеева Н.Д., Пучков В.Н., Краснобаев А.А., Козлова О.В., Ратов А.А. Ашинская серия венда: орогенный комплекс тиманид на Южном Урале // Геол. вестник, 2019, №1, с. 3-34.

Сергеева Н.Д., Пучков В.Н., Ратов А.А., Козлова О.В. Стратиграфическая корреляция отложений рифея Волго-Уральской области и Южного Урала и их пространственное взаимоотношение в зоне сопряжения платформенных и складчатых структур по сейсмическим материалам // Геол. вестник, 2018, № 2, с. 79-95.

Стратиграфическая схема рифейских и вендских отложений Волго-Уральской области. Уфа: ИГ УНЦ РАН, 2000. 2 л.

Стратиграфический кодекс России. Издание третье, исправленное и дополненное. СПб, Изд-во ВСЕГЕИ, 2019, 96 с.

Стратотип рифея. Стратиграфия. Геохронология. М., Наука, 1983, 184 с.

Чибрикова Е.В., Олли В.А. Новые находки органических остатков в допалеозойских (?) отложениях Урала. Материалы VII Межрегиональной геологической конференции. Уфа, 2008, с. 132-134.

Чумаков Н.М. Оледенения Земли: история, стратиграфическое значение и роль в биосфере. М., ГЕОС, 2015, 160 с.

Чумаков Н.М. Опорный разрез вендских ледниковых отложений Южного Урала (кургашлинская свита Криволукского грабена) // Урал: фундаментальные проблемы геодинамики и стратиграфии. М.: Наука, 1998, с. 138-153. 
Чумаков Н.М., Покровский Б.Г., Маслов А.В. Стратиграфическое положение и значение карбонатных пород, связанных с неопротерозойскими ледниковыми горизонтами Урала // Стратиграфия. Геол. корреляция, 2013, т. 21, № 6, с. 3-24.

Шардакова Г.Ю. Отражение гренвильских событий в разных изотопных системах гранитоидов и метаморфитов западного склона Урала // Ежегодник-2017. Тр. ИГГ УрО РАН, вып. 165, 2018, с. 228-232.

Янкаускас Т.В. Микрофоссилии рифея Южного Урала //Стратотип рифея. Палеонтология и палеомагнетизм. М., Наука, 1982, с. 84-120.

Antcliffe J. B. Questioning the evidence of organic compounds called sponge biomarkers // Palaeontology, 2013, v. 56, p. 917-925.

Bartley J.K., Kah L.C., McWilliams J.L., Stagner A.F. Carbon isotope chemostratigraphy of the Middle Riphean type section (Avzyan Formation, Southern Urals, Russia): signal recovery in a fold-and-thrust belt // Chem. Geol., 2007, v. 237, p. 211-232.

Bechstädt T., Jäger H., Rittersbacher A., Schweisfurth B., Spence G., Werner G., Boni M. The Cryogenian Ghaub Formation of Namibia - new insights into Neoproterozoic glaciations // Earth-Sci. Rev., 2018, v. 177, p. 678-714.

Beghin J., Storme J.-Y., Blanpied C., Gueneli N., Brocks J.J., Poulton S.W., Javaux E.J. Microfossils from the late Mesoproterozoic - early Neoproterozoic Atar/ El Mreïti Group, Taoudeni Basin, Mauritania, northwestern Africa // Prec. Res., 2017, v. 291, p. 63-82.

Bowring S.A., Grotzinger J.P., Isachsen C.E., Knoll A.H., Pelechaty S.M., Kolosov P. Calibrating rates of Early Cambrian evolution // Science, 1993, v. 261, p. 1293-1298.

Burchette T.P., Wright V.P. Carbonate ramp depositional systems // Sed. Geol., 1992, v. 79, p. 3-57.

Butterfield N.J. Early evolution of the Eukaryota // Palaeontology, 2015, v. 58(1), p. 5-17.

Canfield D.E. A new model for Proterozoic ocean chemistry // Nature, 1998, v. 396, p. 450-453.

Canfield D.E., Poulton S.W., Knoll A.H., Narbonne G.M., Ross G., Goldberg T., Strauss H. Ferruginous conditions dominated later Neoproterozoic deep-water chemistry // Science, 2008, v. 321, p. 949-952.

Catuneanu O. Principles of Sequence Stratigraphy. Elsevier, Amsterdam, 2006, 375 p.

Cavalier-Smith T. Kingdom Chromista and its eight phyla: a new synthesis emphasising periplastid protein targeting, cytoskeletal and periplastid evolution, and ancient divergences // Protoplasma, 2018, v. 255 (1), p. 297-357.

Cohen P.A., Macdonald F.A. The Proterozoic record of eukaryotes // Paleobiology, 2015, v. 41, p. 610-632.

Cox G.M., Halverson G.P., Stevenson R.K., Vokaty M., Poirier A., Kunzmann M., Li Z.X., Denyszyn S.W., Strauss J.V., Macdonald F.A. Continental flood basalt weathering as a trigger for Neoproterozoic Snowball Earth // Earth Planet. Sci. Lett., 2016, v. 446, p. 89-99.

Cunningham J.A., Vargas K., Yin Z., Bengtson S., Donoghue P.C.J. The Weng'an Biota (Doushantuo Formation): an Ediacaran window on soft-bodied and multicellular microorganisms // J. Geol. Soc. London, 2017, v. 174, №5, p. 793-802.

Derry L.A., Kaufman A.J., Jacobsen S.B. Sedimentary cycling and environmental change in the Late Proterozoic: evidence from stable and radiogenic isotopes // Geochim. Cosmochim. Acta, 1992, v. 56, № 3. p. 1317-1329.

Ernst R.E., Pease V., Puchkov V.N., Kozlov V.I., Sergeeva N.D., Yamilton V. Geochemical Characterization of Precambrian magmatic suites of the southeastern margin of the East European Craton, Southern Urals, Russia // Геологический сборник № 5 ИГ УНЦ РАН. Уфа, ДизайнПолиграфСервис, 2006, с. 119-161. 
Ernst R.E., Wingate M.T.D, Buchan K.L., Li Z.X. Global record of 1600-700 Ma Large Igneous Provinces (LIPs): Implications for the reconstruction of the proposed Nuna (Columbia) and Rodinia supercontinents // Prec. Res., 2008, v. 160, p. 159-178.

Erwin D.H., Laflamme M., Tweedt S.M., Sperling E.A., Pisani D., Peterson K.J. The Cambrian conundrum: Early divergence and later ecological success in the early history of animals // Science, 2011, v.334, p. 1091-1097.

Fairchild I. J., Spencer T., Ali D., Anderson R., Anderton R., Boomer I., Dove D., Evans J., Hambrey M., Howe J., Sawaki Y., Wang Z., Shields G., Zhou Y., Skelton A., Tucker M. Tonian-Cryogenian boundary sections of Argyll, Scotland // Prec. Res., 2018, v. 319, p. 37-64.

Frimmel H.E., Klötzli U.S., Siegfried P.R. New Pb-Pb Single Zircon Age Constraints on the Timing of Neoproterozoic Glaciation and Continental Break-up in Namibia // The Journal of Geology, 1996, v. 104(4), p. 459-469.

Gilleaudeau G.J., Kah L.C. Heterogeneous redox conditions and a shallow chemocline in the Mesoproterozoic ocean: Evidence from carbon-sulfur-iron relationships // Prec. Res., 2015, v. 257, p. 94-108.

Glasmacher U.A., Reynolds P., Alekseev A.A., Puchkov V.N., Taylor K., Gorozhanin V., Walter R. ${ }^{40} \mathrm{Ar}-{ }^{39} \mathrm{Ar}$ Thermochronology west of the Main Uralian Fault, southern Urals, Russia // Geol. Rdsch., 1999, v. 87, p. 515-525.

Gorokhov I.M., Melnikov N.N., Turchenko T.L., Kutyavin E.P., Samsonova E.N. Two illite generations in an Upper Riphean shale: the Rb-Sr isotopic evidence // Terra Nova, 1995, v. 7, p. 330-331.

Grazhdankin D. Patterns of distribution in the Ediacaran biotas: facies versus biogeography and evolution // Paleobiology, 2004, v. 30, p. 203-221.

Grazhdankin D. Patterns of evolution of the Ediacaran soft-bodied biota // Journal of Paleontology, 2014, v. 88, p. 269-283.

Grotzinger J.P. Geochemical model for Proterozoic stromatolite decline // Am. J. Sci., 1990, v. 290-A, p. 80-103.

Halverson G.P., Kunzmann M., Strauss J.V., Maloof A.C. The Tonian-Cryogenian transition in Northeastern Svalbard // Prec. Res., 2018a, v. 319, p. 79-95.

Halverson G.P., Porter S.M., Gibson T.M. Dating the late Proterozoic stratigraphic record // Emerg. Top. Life. Sci., 20186, v. 2 (2), p. 137-147.

Halverson G.P., Wade B.P., Hurtgen M.T., Barovich K.M. Neoproterozoic chemostratigraphy // Prec. Res., 2010, v. 182, p. 337-350.

Hodgskiss M.S.W., Kunzmann M., Poiriere A., Halverson G.P. The role of microbial iron reduction in the formation of Proterozoic molar tooth structures // Earth Planet. Sci. Lett., 2018, v. 482, p. 1-11.

Hoffman P.F. A Neoproterozoic Snowball Earth // Science, 1998, v. 281, p. 1342-1346.

Hoffman P.F., Abbot D.S., Ashkenazy Y., Benn D.I., Brocks J.J., Cohen P.A., Cox G.M., Creveling J.R., Donnadieu Y., Erwin D.H., Fairchild I.J., Ferreira D., Goodman J.C., Halverson G.P., Jansen M.F., Le Hir G., Love G.D., Macdonald F.A., Maloof A.C., Partin C.A., Ramstein G., Rose B.E.J., Rose C.V., Sadler P.M., Tziperman E., Voigt A., Warren S.G. Snowball Earth climate dynamics and Cryogenian geology-geobiology // Science Advances, 2017, v. 3(11), e1600983.

Hofmann M., Linnemann U., Hoffmann K.-H., Germs G., Gerdes A., Marko L., Eckelmann K., Gärtner A., Krause R. The four Neoproterozoic glaciations of southern Namibia and their detrital zircon record: The fingerprints of four crustal growth events during two supercontinent cycles // Prec. Res., 2015, v. 259, p. 176-188. 
International chronostratigraphic chart, v2020/03.

http://www.stratigraphy.org/index.php/ics-chart-timescale

James N.P., Narbonne G.M., Sherman A.G. Molar-tooth carbonates: Shallow subtidal facies of the Mid- to Late Proterozoic // J. Sediment. Res., 1998, v. 68, p. 716-722.

Kasting J.F. Earth's early atmosphere // Science, 1993, v. 259, №5097, p. 920-926.

Knoll A.H., Javaux E.J., Hewitt D., Cohen P. Eukaryotic organisms in Proterozoic oceans // Philos. Trans. R. Soc. B Biol. Sci., 2006, v. 361, p. 1023-1038.

Kolesnikov A.V., Marusin V.V., Nagovitsin K.E., Maslov A.V., Grazhdankin D.V. Ediacaran biota in the aftermath of the Kotlinian Crisis: Asha Group of the South Urals // Prec. Res., 2015, v. 263, p. 59-78.

Krissansen-Totton J., Arney G.N., Catling D.C. Constraining the climate and ocean pH of the early Earth with a geological carbon cycle model // PNAS , v. 115(16), p. 4105-4110.

Kuang H-W. Review of molar tooth structure research // Journal of Palaeogeography, 2014, v. 3, p. 359-383.

Kump L.R. The rise of atmospheric oxygen // Nature, 2008, v. 451, p. 277-278.

Kuznetsov A.B., Bekker A., Ovchinnikova G.V., Gorokhov I.M., Vasilyeva I.M. Unradiogenic strontium and moderate-amplitude carbon isotope variations in early Tonian seawater after the assembly of Rodinia and before the Bitter Springs Excursion // Prec. Res., 2017, v. 298, p. 157-173.

Lamothe K.G., Hoffman P.F., Greenman J.W., Halverson G.P. Stratigraphy and isotope geochemistry of the pre-Sturtian Ugab Subgroup, Otavi/Swakop Group, northwestern Namibia // Prec. Res., 2019, v. 332, 105387.

Levashova N.M., Bazhenov M.L., Meert J.G., Kuznetsov N.B., Golovanova I.V., Danukalov K.N., Fedorova N.M. Paleogeography of Baltica in the Ediacaran: Paleomagnetic and geochronological data from the clastic Zigan Formation, South Urals // Prec. Res., 2013, v. 236, p. 16-30.

Li Z.X., Bogdanova S.V., Collins A.S., Davidson A., De Waele B., Ernst R.E., Fitzsimons I.C.W., Fuck R.A., Gladkochub D.P., Jacobs J., Karlstrom K.E., Lu S., Natapov L.M., Pease V., Pisarevsky S.A., Thrane K., Vernikovsky V. Assembly, configuration, and break-up history of Rodinia: a synthesis // Prec. Res., 2008, v. 160, p. 179-210.

Li Z.X., Evans D.A., Halverson G.P. Neoproterozoic glaciations in a revised global palaeogeography from the breakup of Rodinia to the assembly of Gondwanaland // Sediment. Geol., 2013, v. 294, p. 219-232.

Liu Y., Peltier W.R. Sea level variations during snowball Earth formation: A preliminary analysis // J. Geophys. Res. Solid Earth, 2013, v. 118, p. 4410-4424.

Love G.D., Grosjean E., Stalvies C., Fike D.A., Grotzinger J.P., Bradley A.S., Kelly A.E., Bhatia M., Meredith W., Snape C.E., Bowring S.A., Condon D.J., Summons R.E. Fossil steroids record the appearance of Demospongiae during the Cryogenian period // Nature, 2009, v. 457, p. 718-721.

Lowenstein T.K., Kendall B., Anbar A. The Geologic History of Seawater // Treatise on Geochemistry / Eds. H.D. Holland, K.K. Turekian, 2nd Edition. 2014, v. 8, p. 569-622.

Lyons T.W., Reinhard C.T., Planavsky N.J. The rise of oxygen in Earth's early ocean and atmosphere // Nature, 2014, v. 506, p. 307-315.

Macdonald F.A., Strauss J.V., Sperling E.A., Halverson G.P., Narbonne G.M., Johnston D.T., Kunzmann, M., Schrag D.P., Higgins J.A. The stratigraphic relationship between the Shuram carbon isotope excursion, the oxygenation of Neoproterozoic oceans, and the first appearance of the Ediacara biota and bilaterian trace fossils in northwestern Canada // Chem. Geol., 2013, v. 362, p. 250-272. 
MacLennan S., Eddy M., Merschat A., Mehra A., Crockford P., Maloof A., Southworth C.S., Schoene B. Geologic evidence for an icehouse Earth before the Sturtian global glaciation // Science Advances, 2020, v. 6: eaay6647.

MacLennan S., Park Y., Swanson-Hysell N., Maloof A., Schoene B., Gebreslassie M., Antilla E., Tesema T., Alene M., Haileab B. The arc of the Snowball: U-Pb dates constrain the Islay anomaly and the initiation of the Sturtian glaciations // Geology, 2018, v. 46, p. 539-542.

Miller N.R., Stern R.J., Avigad D., Beyth M., Schilman B. Cryogenian slate-carbonate sequences of the Tambien Group, Northern Ethiopia (I): Pre-«Sturtian» chemostratigraphy and regional correlations // Prec. Res., 2009, v. 170, p. 129-156.

Mitchell R.N., Gernon T.M., Nordsvan A., Cox G.M., Li Z., Hoffman P.F. Hit or miss: Glacial incisions of snowball Earth // Terra Nova, 2019, v. 31, p. 381-389.

Nettersheim B.J., Brocks J.J., Schwelm A., Hope J.M., Not F., Lomas M., Schmidt C., Schiebel R., Nowack E.C.M., de Deckker P., Pawlowski J., Bowser S.S., Bobrovskiy I., Zonneveld K.A.F., Kucera M., Stuhr M., Hallmann C. Putative sponge biomarkers in unicellular Rhizaria question an early rise of animals // Nature Ecology \& Evolution, 2019, v. 3, p. 577-581.

Park Y., Swanson-Hysell N.L., MacLennan S.A., Maloof A.C., Gebreslassie M., Tremblay M.M., Schoene B., Alene M., Anttila E.S.C., Tesema T., Haileab B. The lead-up to the Sturtian Snowball Earth: Neoproterozoic chemostratigraphy time-calibrated by the Tambien Group of Ethiopia // GSA Bulletin, 2020, v. 132, p. 1119-1149.

Planavsky N.J., Tarhan L.G., Bellefroid E.J., Evans D. A. D., Reinhard C.T., Love G.D., Lyons T.W. Late Proterozoic transitions in climate, oxygen, and tectonics, and the rise of complex life // Earth-Life Transitions: Paleobiology in the Context of Earth System Evolution. The Paleontological Society Papers, v. 21 / Eds P.D. Polly, J.J. Head, D.L. Fox. 2015, p. 1-36.

Porter S. Calcite and aragonite seas and the de novo acquisition of carbonate skeletons // Geobiology, 2010, v. 8, p. 256-277.

Pu J.P., Bowring S.A., Ramezani J., Myrow P., Raub T.D., Landing E., Mills A., Hodgin E., Macdonald F.A. Dodging snowballs: Geochronology of the Gaskiers glaciation and the first appearance of the Ediacaran biota // Geology, 2016, v. 44, p. 955-958.

Puchkov V.N., Krasnobaev A.A., Sergeeva N.D. The New Data on Stratigraphy of the Riphean Stratotype in the Southern Urals, Russia // Journal of Geoscience and Environment Protection, 2014, v. 2, p. 108-116.

Riding R. Cyanobacterial calcification, carbon dioxide concentrating mechanisms, and Proterozoic-Cambrian changes in atmospheric composition // Geobiology, 2006, v. 4, p. 299-316.

Rooney A.D., Strauss J.V., Brandon A.D., Macdonald F.A. A Cryogenian chronology: Two long-lasting synchronous Neoproterozoic glaciations // Geology, 2015, v. 43, p. 459-462.

Rothman D.H., Hayes J.M., Summons R.E. Dynamics of the Neoproterozoic carbon cycle // PNAS, 2003, v. 100, p. 8124-8129.

Sahoo S.K., Planavsky N.J., Jiang G., Kendall B., Owens J.D., Wang X., Shi X., Anbar A.D., Lyons T.W. Oceanic oxygenation events in the anoxic Ediacaran ocean // Geobiology, 2016, v. 14, p. 457-468.

Seilacher A. Vendobionta and Psammocorallia: lost constructions of Precambrian evolution // J. Geol. Soc. London, 1992, v. 149, p. 607-613.

Sheldon N.D. Precambrian paleosols and atmospheric $\mathrm{CO}_{2}$ levels // Prec. Res., 2006, v. 147 (1-2), p. 148-155.

Shields G.A. «Molar-tooth microspar»: A chemical explanation for its disappearance 750 Ma // Terra Nova, 2002, v. 14, p. 108-113.

Shields G.A., Halverson G.P., Porter S.M. Descent into the Cryogenian // Prec. Res., 2018, v. 319, p. $1-5$. 
Sperling E.A., Rooney A.D., Hays L., Sergeev V.N., Vorob'eva N.G., Sergeeva N.D., Selby D., Johnston D.T., Knoll A.H. Redox heterogeneity of subsurface waters in the Mesoproterozoic ocean // Geobiology, 2014, v. 12, p. 373-386.

Sperling E.A., Wolock C.J., Morgan A.S., Gill B.C., Kunzmann M., Halverson G.P., Macdonald F.A., Knoll A.H., Johnston D.T. Statistical analysis of iron geochemical data suggests limited late Proterozoic oxygenation // Nature, 2015, v. 523, p. 451-454.

Swanson-Hysell N.L., Maloof A.C., Condon D.J., Jenkin G.R.T., Alene M., Tremblay M.M., Tesema T., Rooney A.D., Hailea B. Stratigraphy and geochronology of the Tambien Group, Ethiopia: evidence for globally synchronous carbon isotope change in the Neoproterozoic // Geology, 2015, v. 43, p. 323-326.

Van der Meer D.G., van den Berg van Saparoea A.P.H., van Hinsbergen D.J.J., van deWeg R.M.B., Godderis Y., Le Hir G., Donnadieu Y. Reconstructing first-order changes in sea level during the Phanerozoic and Neoproterozoic using strontium isotopes // Gondwana Res., 2017, v. 44, p. 22-34.

Wallace M.W., Shuster A., Greig A., Planavsky N.J., Reed C.P. Oxygenation history of the Neoproterozoic to early Phanerozoic and the rise of land plants // Earth Planet. Sci. Lett., 2017, v. 466, p. 12-19.

Williams G.E., Gostin V.A. Late Cryogenian glaciation in South Australia: fluctuating ice margin and no extreme or rapid post-glacial sea-level rise // Geoscience Frontiers, 2019, v. 10(4), p. 1397-1408.

Williams J.J., Mills B.J.W., Lenton T.M. A tectonically driven Ediacaran oxygenation event // Nature Communications, 2019, v. 10(1), p. 1-10.

Willner A.P., Ermolaeva T., Stroink L., Glasmacher U.A., Giese U., Puchkov V.N., Kozlov V.I., Walter R. Contrasting provenance signals in Riphean and Vendian sandstones in the SW Urals (Russia): constraints for a change from passive to active continental margin conditions in the Neoproterozoic // Prec. Res., 2001, v. 110(1-4), p. 215-239.

Xiao S., Zhang Y., Knoll A.H. Three-dimensional preservation of algae and animal embryos in a Neoproterozoic phosphorite // Nature, 1998, v. 391, p. 553-558.

Xu B., Xiao S., Zou H., Chen Y., Li Z., Song B., Liu D., Zhou C., Yuan X. SHRIMP zircon U-Pb age constraints on Neoproterozoic Quruqtagh diamictites in NW China // Prec. Res., 2009, v. 168(3-4), p. 247-258.

Yin L., Zhu M., Knoll A.H., Yuan X., Zhang J., Hu J. Doushantuo embryos preserved inside diapause egg cysts // Nature, 2007, v. 446, p. 661-663.

Zaky A.H., Brand U., Buhl D., Blamey N., Bitner M.A., Logan A. Strontium isotope geochemistry of modern and ancient archives: tracer of secular change in ocean chemistry // Can. J. Earth Sci., 2019, v. 56(3), p. 245-264.

Zhou Y., Pogge von Strandmann P.A.E., Zhu M., Ling H., Manning C., Li D., He T., Shields G.A. Reconstructing Tonian seawater ${ }^{87} \mathrm{Sr} /{ }^{86} \mathrm{Sr}$ using calcite microspar // Geology, 2020, v. 48, p. 462-467.

Zhuravlev A.Yu., Wood R.A. The two phases of the Cambrian Explosion // Sci. Rep., 2018, v. 8, 16656. 


\section{ПОДРИСУНОЧНЫЕ ПОДПИСИ}

Рис. 1. А - Расчленение неопротерозоя МСШ и вариации изотопного состава углерода и стронция; голубым цветом показаны интервалы глобальных (Стёрт и Марино / Элатина) и субглобальных (Гаскье) оледенений [по данным Miller et al., 2009; Macdonald et al., 2013; Swanson-Hysell et al., 2015; Rooney et al., 2015; Cox et al., 2016; Pu et al., 2016; Halverson et al., 2018a; Lamothe et al., 2019; Zaky et al., 2019; Zhou et al., 2020]. Б - Сводный разрез зильмердакско-ашинской последовательности БМА на основе имеющихся к настоящему моменту данных. Схематично показано наиболее вероятное положение стратиграфических подразделений. Ширина цветных полос характеризует неопределённость в стратиграфической приуроченности свит. Серии: I - зильмердакская, II - каратауская, III - аршинская, IV - ашинская. Составлено с использованием [Стратотип..., 1983; Горожанин, 1995; Овчинникова и др., 1998; Подковыров и др., 1998; Маслов, 2000, 2020; Маслов и др., 1994, 2001, 2018а; Вейс и др., 2003; Кузнецов и др., 2006, 2014; Зайцева и др., 2008, 2019; Сергеев и др., 2010; Пучков и др., 2010; Козлов и др., 2011; Гражданкин и др., 2011; Кузнецов, Шацилло, 2011; Краснобаев и др., 2012, 2019; Беккер, 2013; Levashova et al., 2013; Пучков и др., 2014, 2017; Генина и др., 2015; Чумаков, 2015; Kolesnikov et al., 2015; Гражданкин, Маслов, 2015; Ларионов и др., 2015; Горожанин, Канипова, 2017; Kuznetsov et al., 2017; Разумовский, 2018; Разумовский и др., 2020] и на основе предложений по совершенствованию ОСШ [Дуб, в печати]. В - условные обозначения к Б: 1 - акантоморфные акритархи, 2 - раковинные (панцирные) амёбы, 3 вендские / эдиакарские макроископаемые, 4 - цирконы (d - детритовые), 5 - глауконит, 6 тиллиты и кэп-карбонаты, 7 - МТ-текстуры, 8 - карбонатные отложения, 9 - существенно терригенные отложения, 10 - свиты с признаками марино-гляциального генезиса.

Рис. 2. Карта докембрийских образований Башкирского мегантиклинория в границах листа N-40 (на основе [Государственная..., 2013]). Откартированы местные стратиграфические подразделения. Условные обозначения: 1 - расположение листа карты $\mathrm{N}-40$ на схеме РФ, 2 - дорифейские образования, 3 - бурзянская серия, 4 - юрматинская серия, 5 - зильмердакская серия, 6 - каратауская серия, 7 - аршинская и ашинская серии, 8 - палеозойские отложения, 9 - интрузивные тела, 10 - вулканические и гипабиссальные образования, 11 - стратиграфические границы, 12 - тектонические границы, 13 - крупные реки, 14 - главные автодороги, 15 - населённые пункты, 16 - железные дороги. 


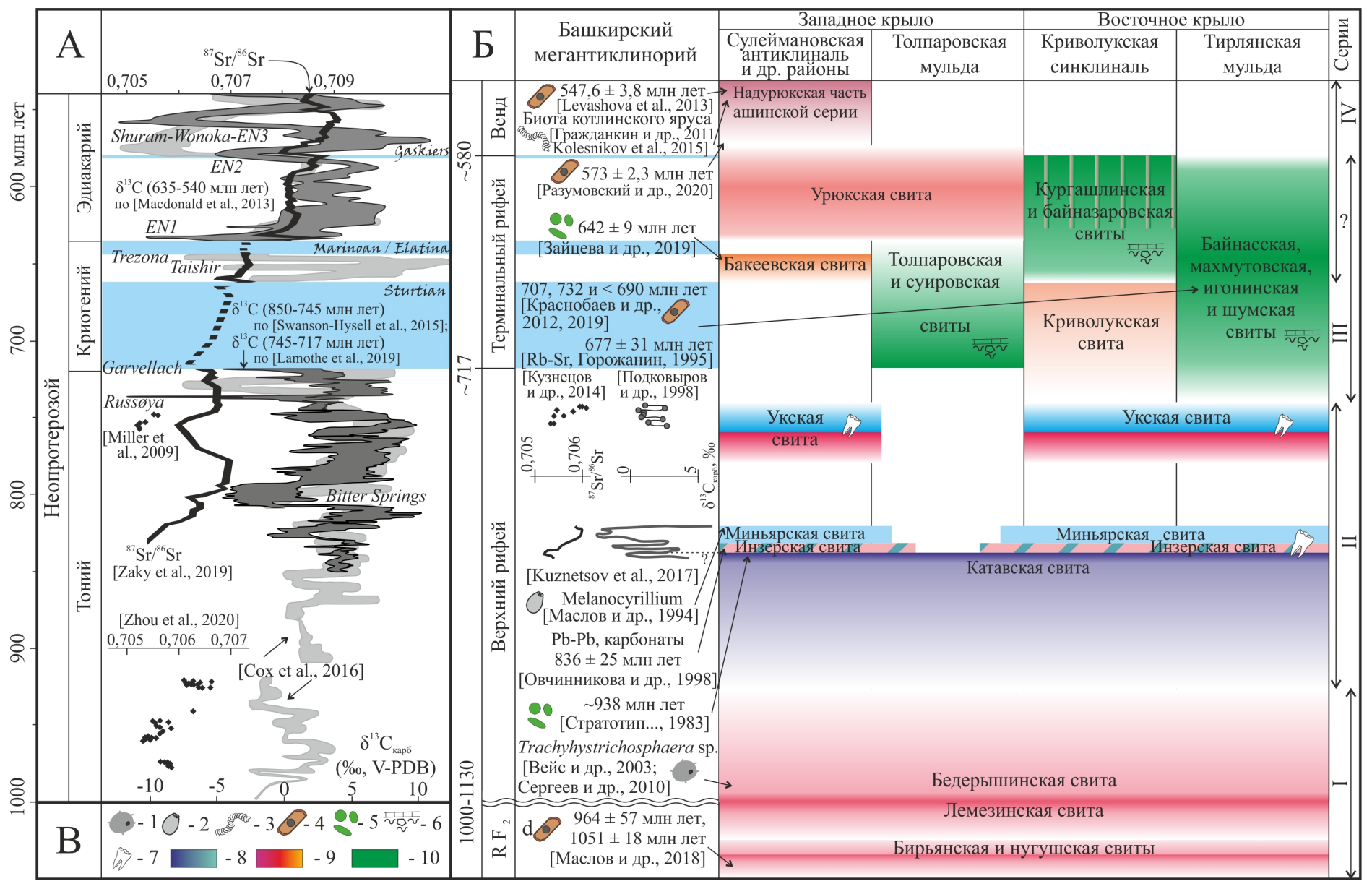




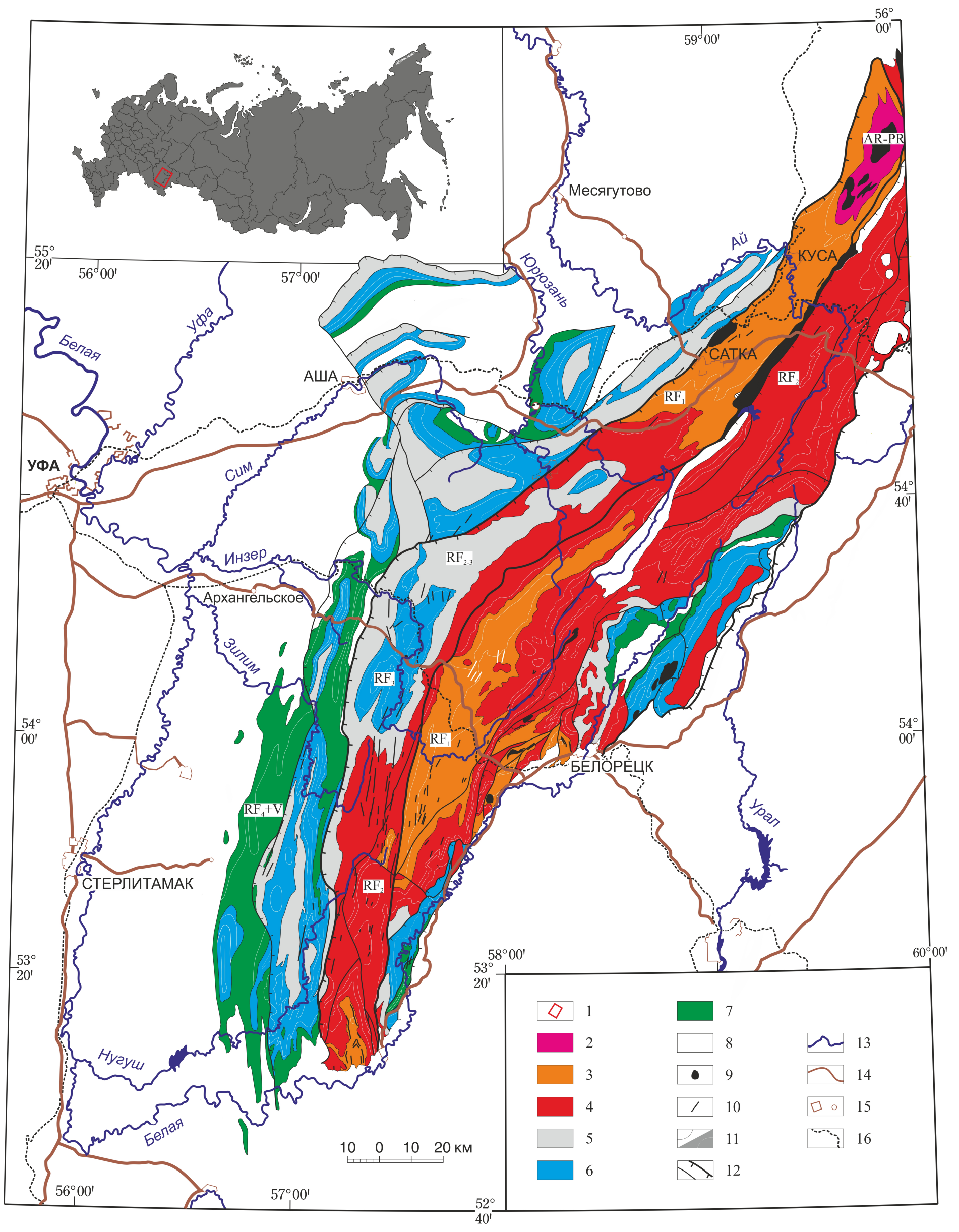

